4

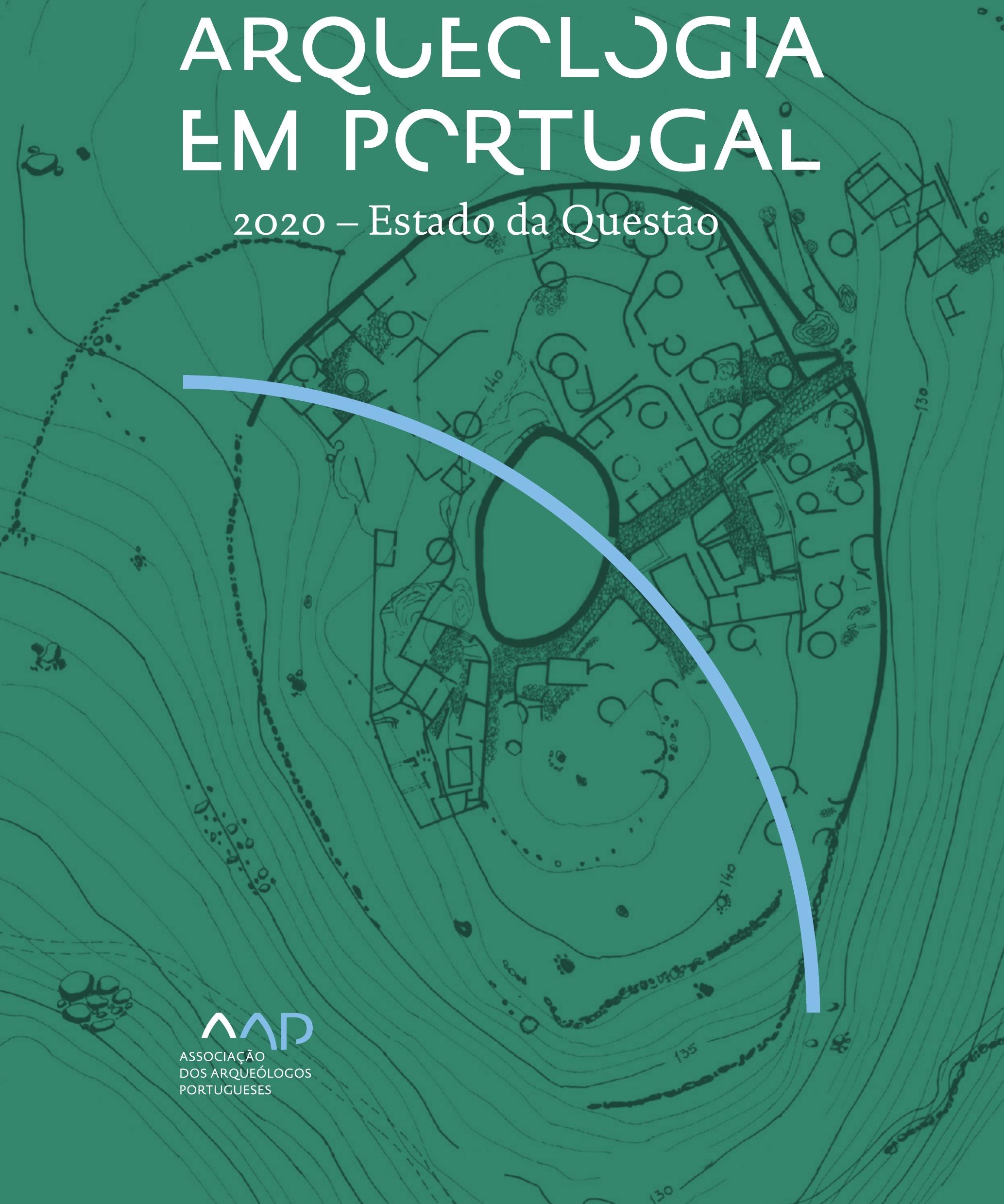


Coordenação editorial: José Morais Arnaud, César Neves e Andrea Martins Design gráfico: Flatland Design

AAP - ISBN: 978-972-9451-89-8

CITCEM - ISBN: 978-989-8970-25-1

Associação dos Arqueólogos Portugueses e CITCEM

Lisboa, 2020

O conteúdo dos artigos é da inteira responsabilidade dos autores. Sendo assim a Associação dos Arqueólogos Portugueses declina qualquer responsabilidade por eventuais equívocos ou questões de ordem ética e legal.

Desenho de capa:

Planta do castro de Monte Mozinho (Museu Municipal de Penafiel).

\section{$\hat{\wedge} \mathrm{P}$}

DOS ARQUEÓLOGOS PORTUGUESES

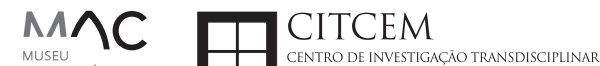
MUSEU
ARQUELLÓGICO
DO CARMO
U.PORTO

FLUP FACULDADE DE LETRAS
UNIVERSIDADE DO PORTO

Apoio

EC para a Ciência 


\section{Índice}

15 Prefácio

José Morais Arnaud

\section{Historiografia e Teoria}

17 Território, comunidade, memória e emoção: a contribuição da história da arqueologia (algumas primeiras e breves reflexões)

Ana Cristina Martins

25 Como descolonizar a arqueologia portuguesa?

Rui Gomes Coelho

41 Arqueologia e Modernidade: uma revisitação pessoal e breve de alguns aspetos da obra homónima de Julian Thomas de 2004

Vítor Oliveira Jorge

57 Dados para a História das Mulheres na Arqueologia portuguesa, dos finais do século XIX aos inícios do século XX: números, nomes e tabelas

Filipa Dimas / Mariana Diniz

73 Retractos da arqueologia portuguesa na imprensa: (in)visibilidades no feminino

Catarina Costeira / Elsa Luís

85 Arqueologia e Arqueólogos no Norte de Portugal Jacinta Bugalhão

101 Vieira Guimarães (1864-1939) e a arqueologia em Tomar: uma abordagem sobre o território e as gentes

João Amendoeira Peixoto / Ana Cristina Martins

115 Os memoráveis? A arqueologia algarvia na imprensa nacional e regional na presente centúria (2001-2019): características, visões do(s) passado(s) e a arqueologia

enquanto marca

Frederico Agosto / João Silva

129 A Evolução da Arqueologia Urbana e a Valorização Patrimonial no Barlavento Algarvio: Os casos de Portimão e Silves

Artur Mateus / Diogo Varandas / Rafael Boavida

\section{Gestão, Valorização e Salvaguarda do Património}

145 O Caderno Reivindicativo e as condições de trabalho em Arqueologia Miguel Rocha / Liliana Matias Carvalho / Regis Barbosa / Mauro Correia / Sara Simões / Jacinta Bugalhão / Sara Brito / Liliana Veríssimo Carvalho / Richard Peace / Pedro Peça / Cézer Santos

155 Os Estudos de Impacte Patrimonial como elemento para uma estratégia sustentável de minimização de impactes no âmbito de reconversões agrícolas Tiago do Pereiro

165 Salvaguarda de Património arqueológico em operações florestais: gestão e sensibilização Filipa Bragança / Gertrudes Zambujo / Sandra Lourenço / Belém Paiva / Carlos Banha / Frederico Tatá Regala / Helena Moura / Jacinta Bugalhão / João Marques / José Correia / Pedro Faria / Samuel Melro

179 Os valores do Património: uma investigação sobre os Sítios Pré-históricos de Arte Rupestre do Vale do Rio Côa e de Siega Verde José Paulo Francisco 
189 Conjugando recursos arqueológicos e naturais para potenciar as visitas ao Geoparque Litoral de Viana do Castelo (Noroeste de Portugal)

Hugo A. Sampaio / Ana M.S. Bettencourt / Susana Marinho / Ricardo Carvalhido

203 Áreas de Potencial Arqueológico na Região do Médio Tejo: Modelo Espacial Preditivo Rita Ferreira Anastácio / Ana Filipa Martins / Luiz Oosterbeek

223 Património Arqueológico e Gestão Territorial: O contributo da Arqueologia para a revisão do PDM de Avis

Ana Cristina Ribeiro

237 A coleção arqueológica do extinto Museu Municipal do Porto - Origens, Percursos e Estudos

Sónia Couto

251 Valpaços - uma nova carta arqueológica

Pedro Pereira / Maria de Fátima Casares Machado

263 Arqueologia na Cidade de Peniche

Adriano Constantino / Luís Rendeiro

273 Arqueologia Urbana: a cidade de Lagos como caso de Estudo Cátia Neto

285 Estratégias de promoção do património cultural subaquático nos Açores. O caso da ilha do Faial

José Luís Neto / José Bettencourt / Luís Borges / Pedro Parreira

297 Carta Arqueológica da Cidade Velha: Uma primeira abordagem

Jaylson Monteiro / Nireide Tavares / Sara da Veiga / Claudino Ramos / Edson Brito /

Carlos Carvalho / Francisco Moreira / Adalberto Tavares

311 Antropologia Virtual: novas metodologias para a análise morfológica e funcional Ricardo Miguel Godinho / Célia Gonçalves

\section{Didáctica da Arqueologia}

327 Como os projetos de Arqueologia podem contribuir para uma comunidade culturalmente mais consciente Alexandra Figueiredo / Claúdio Monteiro / Adolfo Silveira / Ricardo Lopes

337 Educação Patrimonial - Um cidadão esclarecido é um cidadão ativo! Ana Paula Almeida

351 A aproximação da Arqueologia à sala de aula: um caso de estudo no $3^{\circ}$ ciclo do Ensino Básico Luís Serrão Gil

363 Arqueologia 3.o - Pensar e comunicar a Arqueologia para um futuro sustentável Mónica Rolo

377 “Conversa de Arqueólogos" - Divulgar a Arqueologia em tempos de Pandemia Diogo Teixeira Dias

389 Escola Profissional de Arqueologia: desafios e oportunidades Susana Nunes / Dulcineia Pinto / Júlia Silva / Ana Mascarenhas

399 Os Museus de Arqueologia e os Jovens: a oferta educativa para o público adolescente Beatriz Correia Barata / Leonor Medeiros

411 O museu universitário como mediador entre a ciência e a sociedade: o exemplo da secção de arqueologia no Museu de História Natural e da Ciência da Universidade do Porto (MHNC-UP)

Rita Gaspar 
421 Museu de Lanifícios: Real Fábrica de Panos. Atividades no âmbito da Arqueologia Beatriz Correia Barata / Rita Salvado

427 Arqueologia Pública e o caso da localidade da Mata (Torres Novas) Cláudia Manso / Ana Rita Ferreira / Cristiana Ferreira / Vanessa Cardoso Antunes

431 Do sítio arqueológico ao museu: um percurso (também) didático Lídia Fernandes

447 Estão todos convidados para a Festa! E para dançar também... O projecto do Serviço Educativo do Museu Arqueológico do Carmo na $5^{\underline{a}}$ Edição da Festa da Arqueologia Rita Pires dos Santos

459 O “Clã de Carenque”, um projeto didático de arqueologia Eduardo Gonzalez Rocha

469 Mediação cultural: peixe que puxa carroça nas Ruínas Romanas de Troia Inês Vaz Pinto / Ana Patrícia Magalhães / Patrícia Brum / Filipa Santos

481 Didática Arqueológica, experiências do Projeto Mértola Vila Museu Maria de Fátima Palma / Clara Rodrigues / Susana Gómez / Lígia Rafael

\section{Arte Rupestre}

497 Os inventários de arte rupestre em Portugal Mila Simões de Abreu

513 O projeto FIRST-ART - conservação, documentação e gestão das primeiras manifestações de arte rupestre no Sudoeste da Península Ibérica: as grutas do Escoural e Maltravieso Sara Garcês / Hipólito Collado / José Julio García Arranz / Luiz Oosterbeek / António Carlos Silva / Pierluigi Rosina / Hugo Gomes / Anabela Borralheiro Pereira / George Nash / Esmeralda Gomes / Nelson Almeida / Carlos Carpetudo

523 Trabalhos de documentação de arte paleolítica realizados no âmbito do projeto PalæoCôa André Tomás Santos / António Fernando Barbosa / Luís Luís / Marcelo Silvestre / Thierry Aubry

537 Imagens fantasmagóricas, silhuetas elusivas: as figuras humanas na arte do Paleolítico Superior da região do Côa Mário Reis

$55^{1}$ Os motivos zoomórficos representados nas placas de tear de Vila Nova de São Pedro (Azambuja, Portugal) Andrea Martins / César Neves / José M. Arnaud / Mariana Diniz

571 Arte Rupestre do Monte de Góios (Lanhelas, Caminha). Síntese dos resultados dos trabalhos efectuados em 2007-2009 Mário Varela Gomes

599 Gravuras rupestres de barquiformes no Monte de S. Romão, Guimarães, Noroeste de Portugal Daniela Cardoso

613 Círculos segmentados gravados na Bacia do Rio Lima (Noroeste de Portugal): contributos para o seu estudo Diogo Marinho / Ana M.S. Bettencourt / Hugo Aluai Sampaio

631 Equídeos gravados no curso inferior do Rio Mouro, Monção (NW Portugal). Análise preliminar Coutinho, L.M. / Bettencourt, A.M.S / Sampaio, Hugo A.S

645 Paletas na Arte Rupestre do Noroeste de Portugal. Inventário preliminar Bruna Sousa Afonso / Ana M. S. Bettencourt / Hugo A. Sampaio 


\section{Pré-História}

661 O projeto Miño/Minho: balanço de quatro anos de trabalhos arqueológicos Sérgio Monteiro-Rodrigues / João Pedro Cunha-Ribeiro / Eduardo Méndez-Quintas / Carlos Ferreira / Pedro Xavier / José Meireles / Alberto Gomes / Manuel Santonja / Alfredo Pérez-González

677 A ocupação paleolítica da margem esquerda do Baixo Minho: a indústria lítica do sítio de Pedreiras 2 (Monção, Portugal) e a sua integração no contexto regional Carlos Ferreira / João Pedro Cunha-Ribeiro / Sérgio Monteiro-Rodrigues / Eduardo Méndez-Quintas / Pedro Xavier / José Meireles / Alberto Gomes / Manuel Santonja / Alfredo Pérez-González

693 O sítio acheulense do Plistocénico médio da Gruta da Aroeira Joan Daura / Montserrat Sanz / Filipa Rodrigues / Pedro Souto / João Zilhão

703 As sociedades neandertais no Barlavento algarvio: modelos preditivos com recurso aos SIG

Daniela Maio

715 A utilização de quartzo durante o Paleolítico Superior no território dos vales dos rios Vouga e Côa

Cristina Gameiro / Thierry Aubry / Bárbara Costa / Sérgio Gomes / Luís Luís / Carmen Manzano / André Tomás Santos

733 Uma perspetiva diacrónica da ocupação do concheiro do Cabeço da Amoreira (Muge, Portugal) a partir da tecnologia lítica Joana Belmiro / João Cascalheira / Célia Gonçalves

745 Novos dados sobre a Pré-história Antiga no concelho de Palmela. A intervenção arqueológica no sítio do Poceirão I

Michelle Teixeira Santos

757 Problemas em torno de Datas Absolutas Pré-Históricas no Norte do Alentejo Jorge de Oliveira

771 Povoamento pré-histórico nas áreas montanhosas do NO de Portugal: o Abrigo 1 de Vale de Cerdeira Pedro Xavier / José Meireles / Carlos Alves

783 Apreciação do povoamento do Neolítico Inicial na Baixa Bacia do Douro. A Lavra I (Serra da Aboboreira) como caso de estudo Maria de Jesus Sanches

797 O Processo de Neolitização na Plataforma do Mondego: os dados do Sector C do Outeiro dos Castelos de Beijós (Carregal do Sal)

João Carlos de Senna-Martinez / José Manuel Quintã Ventura / Andreia Carvalho / Cíntia Maurício

823 Novos trabalhos na Lapa da Bugalheira (Almonda, Torres Novas) Filipa Rodrigues / Pedro Souto / Artur Ferreira / Alexandre Varanda / Luís Gomes / Helena Gomes / João Zilhão

837 A pedra polida e afeiçoada do sítio do Neolítico médio da Moita do Ourives (Benavente, Portugal)

César Neves

857 Casal do Outeiro (Encarnação, Mafra): novos contributos para o conhecimento do povoamento do Neolítico final na Península de Lisboa.

Cátia Delicado / Carlos Maneira e Costa / Marta Miranda / Ana Catarina Sousa

873 Stresse infantil, morbilidade e mortalidade no sítio arqueológico do Neolítico Final/ Calcolítico ( $4^{\circ}$ e $3^{\circ}$ milénio a.C.) do Monte do Carrascal 2 (Ferreira do Alentejo, Beja) Liliana Matias de Carvalho / Sofia N. Wasterlain 
885 Come together: O Conjunto Megalítico das Motas (Monção, Viana do Castelo) e as expressões Campaniformes do Alto Minho Ana Catarina Basílio / Rui Ramos

899 Trabalhos arqueológicos no sítio Calcolítico da Pedreira do Poio Carla Magalhães / João Muralha / Mário Reis / António Batarda Fernandes

913 O sítio arqueológico de Castanheiro do Vento. Da arquitectura do sítio à arquitectura de um território João Muralha Cardoso

925 Estudo zooarqueológico das faunas do Calcolítico final de Vila Nova de São Pedro (Azambuja, Portugal): Campanhas de 2017 e 2018 Cleia Detry / Ana Catarina Francisco / Mariana Diniz / Andrea Martins / César Neves / José Morais Arnaud

943 As faunas depositadas no Museu Arqueológico do Carmo provenientes de Vila Nova de São Pedro (Azambuja): as campanhas de 1937 a 1967 Ana Catarina Francisco / Cleia Detry / César Neves / Andrea Martins / Mariana Diniz / José Morais Arnaud

959 Análise funcional de material lítico em sílex do castro de Vila Nova de S. Pedro (Azambuja, Portugal): uma primeira abordagem Rafael Lima

971 O recinto da Folha do Ouro 1 (Serpa) no contexto dos recintos de fossos calcolíticos alentejanos

António Carlos Valera / Tiago do Pereiro / Pedro Valério / António M. Monge Soares

\section{Proto-História}

987 Produção de sal marinho na Idade do Bronze do noroeste Português. Alguns dados para uma reflexão

Ana M. S. Bettencourt / Sara Luz / Nuno Oliveira / Pedro P. Simões / Maria Isabel C. Alves / Emílio Abad-Vidal

1001 A estátua-menir do Pedrão ou de São Bartolomeu do Mar (Esposende, noroeste de Portugal) no contexto arqueológico da fachada costeira de entre os rios Neiva e Cávado Ana M. S. Bettencourt / Manuel Santos-Estévez / Pedro Pimenta Simões / Luís Gonçalves

1015 O Castro do Muro (Vandoma/Baltar, Paredes) - notas para uma biografia de ocupação da Idade do Bronze à Idade Média

Maria Antónia D. Silva / Ana M. S. Bettencourt / António Manuel S. P. Silva / Natália Félix

1031 Do Bronze Final à Idade Média - continuidades e hiatos na ocupação de Povoados em Oliveira de Azeméis João Tiago Tavares / Adriaan de Man

1041 As faunas do final da Idade do Bronze no Sul de Portugal: leituras desde o Outeiro do Circo (Beja)

Nelson J. Almeida / Íris Dias / Cleia Detry / Eduardo Porfírio / Miguel Serra

1055 A Espada do Monte das Oliveiras (Serpa) - uma arma do Bronze Pleno do Sudoeste Rui M. G. Monge Soares / Pedro Valério / Mariana Nabais / António M. Monge Soares

1065 São Julião da Branca (Albergaria-a-Velha) - Investigação e valorização de um povoado do Bronze Final

António Manuel S. P. Silva / Paulo A. P. Lemos / Sara Almeida e Silva / Edite Martins de Sá

1083 Do castro de S. João ao Mosteiro de Santa Clara: notícia de uma intervenção arqueológica, em Vila do Conde Rui Pinheiro 
1095 O castro de Ovil (Espinho), um quarto de século de investigação - resultados e questões em aberto

Jorge Fernando Salvador / António Manuel S. P. Silva

1111 O Castro de Salreu (Estarreja), um povoado proto-histórico no litoral do Entre Douro e Vouga

Sara Almeida e Silva / António Manuel S. P. Silva / Paulo A. P. Lemos / Edite Martins de Sá

1127 Castro de Nossa Senhora das Necessidades (Sernancelhe): uma primeira análise artefactual Telma Susana O. Ribeiro

${ }_{1141}$ A cividade de Bagunte. O estado atual da investigação Pedro Brochado de Almeida

1153 Zoomorfos na cerâmica da Idade do Ferro no NW Peninsular: inventário, cronologias e significado Nuno Oliveira / Cristina Seoane

1163 Vasos gregos em Portugal: diferentes maneiras de contar a história do intercâmbio cultural na Idade do Ferro

Daniela Ferreira

1175 Os exotica da necrópole da Idade do Ferro do Olival do Senhor dos Mártires (Alcácer do Sal) no seu contexto regional

Francisco B. Gomes

\section{Antiguidade Clássica e Tardia}

1191 O uso de madeira como combustível no sítio da Quinta de Crestelos (Baixo Sabor): da Idade do Ferro à Romanização Filipe Vaz / João Tereso / Sérgio Simões Pereira / José Sastre / Javier Larrazabal Galarza / Susana Cosme / José António Pereira / Israel Espi

1207 Cultivos de Época Romana no Baixo Sabor: continuidade em tempos de mudança? João Pedro Tereso / Sérgio Simões Pereira / Filipe Santos / Luís Seabra / Filipe Vaz

1221 A casa romana na Hispânia: aplicação dos modelos itálicos nas províncias ibéricas Fernanda Magalhães / Diego Machado / Manuela Martins

1235 As pinturas murais romanas da Rua General Sousa Machado, n. ${ }^{5}$ 1, Chaves José Carvalho

1243 Trás do Castelo (Vale de Mir, Pegarinhos, Alijó) - Uma exploração agrícola romana do Douro

Tony Silvino / Pedro Pereira

1255 A sequência de ocupação no quadrante sudeste de Bracara Augusta: as transformações de uma unidade doméstica Lara Fernandes / Manuela Martins

1263 Os Mosaicos com decoração geométrica e geométrico-vegetalista dos sítios arqueológicos da área do Conuentus Bracaraugustanus. Novas abordagens quanto à conservação, restauro, decoração e datação Maria de Fátima Abraços / Licínia Wrench

1277 “Casa Romana” do Castro de São Domingos (Cristelos, Lousada): Escavação, Estudo e Musealização Paulo André de P. Lemos

1291 A arqueobotânica no Castro de Guifões (Matosinhos, Noroeste de Portugal): O primeiro estudo carpológico

Luís Seabra / Andreia Arezes / Catarina Magalhães / José Varela / João Pedro Tereso 
1305 Um Horreum Augustano na Foz do Douro (Monte do Castelo de Gaia, Vila Nova de Gaia) Rui Ramos

1311 Ponderais romanos na Lusitânia: padrões, formas, materiais e contextos de utilização Diego Barrios Rodríguez

1323 Um almofariz centro-itálico na foz do Mondego

Marco Penajoia

1335 Estruturas romanas de Carnide - Lisboa Luísa Batalha / Mário Monteiro / Guilherme Cardoso

1347 O contexto funerário do sector da "necrópole NO" da Rua das Portas de S. Antão (Lisboa): o espaço, os artefactos, os indivíduos e a sua interconectividade na interpretação do passado Sílvia Loja, José Carlos Quaresma, Nelson Cabaço, Marina Lourenço, Sílvia Casimiro, Rodrigo Banha da Silva, Francisca Alves-Cardoso

${ }_{1361}$ Povoamento em época Romana na Amadora - resultados de um projeto pluridisciplinar Gisela Encarnação / Vanessa Dias

1371 A Arquitectura Residencial em Mirobriga (Santiago do Cacém): contributo a partir de um estudo de caso Filipe Sousa / Catarina Felício

${ }_{1385}$ O fim do ciclo. Saneamento e gestão de resíduos nos edifícios termais de Mirobriga (Santiago do Cacém)

Catarina Felício / Filipe Sousa

1399 Balsa, Topografia e Urbanismo de uma Cidade Portuária Vítor Silva Dias / João Pedro Bernardes / Celso Candeias / Cristina Tété Garcia

1413 No Largo das Mouras Velhas em Faro (2017): novas evidências da necrópole norte de Ossonoba e da sua ocupação medieval Ricardo Costeira da Silva / Paulo Botelho / Fernando Santos / Liliana Nunes

1429 Instrumentos de pesca recuperados numa fábrica de salga em Ossonoba (Faro) Inês Rasteiro / Ricardo Costeira da Silva / Paulo Botelho

1439 A Necrópole Romana do Eirô, Duas Igrejas (Penafiel): intervenção arqueológica de 2016 Laura Sousa / Teresa Soeiro

1457 Ritual, descarte ou afetividade? A presença de Canis lupus familiaris na Necrópole Noroeste de Olisipo (Lisboa)

Beatriz Calapez Santos / Sofia Simões Pereira / Rodrigo Banha da Silva / Sílvia Casimiro / Cleia Detry / Francisca Alves Cardoso

1467 Dinâmicas económicas em Bracara na Antiguidade Tardia Diego Machado / Manuela Martins / Fernanda Magalhães / Natália Botica

1479 Cerâmicas e Vidros da Antiguidade Tardia do Edifício sob a Igreja do Bom Jesus (Vila Nova de Gaia) Joaquim Filipe Ramos

1493 Novos contributos para a topografia histórica de Mértola no período romano e na Antiguidade Tardia Virgílio Lopes

\section{8. Época Medieval}

1511 Cerâmicas islâmicas no Garb setentrional "português": algumas evidências e incógnitas Constança dos Santos / Helena Catarino / Susana Gómez / Maria José Gonçalves / Isabel Inácio / Gonçalo Lopes / Jacinta Bugalhão / Sandra Cavaco / Jaquelina Covaneiro / Isabel Cristina Fernandes / Ana Sofia Gomes 
1525 Contributo para o conhecimento da cosmética islâmica, em Silves, durante a Idade Média Rosa Varela Gomes

1537 Yábura e o seu território - uma análise histórico-arqueológica de Évora entre os séculos VIII-XII José Rui Santos

1547 A encosta sul do Castelo de Palmela - resultados preliminares da escavação arqueológica Luís Filipe Pereira / Michelle Teixeira Santos

1559 A igreja de São Lourenço (Mouraria, Lisboa): um conjunto de silos e de cerâmica medieval islâmica

Andreia Filipa Moreira Rodrigues

1571 O registo material de movimentações populacionais no Médio Tejo, durante os séculos XII-XIII. Dois casos de "sunken featured buildings", nos concelhos de Cartaxo e Torres Novas Marco Liberato / Helena Santos / Nuno Santos

1585 O nordeste transmontano nos alvores da Idade média. Notas para reflexão Ana Maria da Costa Oliveira

1601 Sepulturas escavadas na rocha do Norte de Portugal e do Vale do Douro: primeiros resultados do Projecto SER-NPVD

Mário Jorge Barroca / César Guedes / Andreia Arezes / Ana Maria Oliveira

1619 "Portucalem Castrum Novum" entre o Mediterrâneo e o Atlântico: o estudo dos materiais cerâmicos alto-medievais do arqueossítio da rua de D. Hugo, nํ. 5 (Porto) João Luís Veloso

1627 A Alta Idade Média na fronteira de Lafões: notas preliminares sobre a Arqueologia no Concelho de Vouzela

Manuel Luís Real / Catarina Tente

1641 Um conjunto cerâmico medieval fora de portas: um breve testemunho aveirense Susana Temudo

${ }_{1651}$ Os Lóios do Porto: uma perspetiva integrada no panorama funerário da Baixa Idade Média à Época Moderna em meios urbanos em Portugal

Ana Lema Seabra

1659 O Caminho Português Interior de Santiago como eixo viário na Idade Média Pedro Azevedo

1665 Morfologia Urbana: Um exercício em torno do Castelo de Ourém André Donas-Botto / Jaqueline Pereira

1677 Intervenção arqueológica na Rua Marquês de Pombal/Largo do Espírito Santo (Bucelas, Loures)

Florbela Estêvão / Nathalie Antunes-Ferreira / Dário Ramos Neves / Inês Lisboa

1691 O Cemitério Medieval do Poço do Borratém e a espacialidade funerária na cidade de Lisboa Inês Belém / Vanessa Filipe / Vasco Noronha Vieira / Sónia Ferro / Rodrigo Banha da Silva

1705 Um Espaço Funerário Conventual do séc. XV em Lisboa: o caso do Convento de São Domingos da Cidade Sérgio Pedroso / Sílvia Casimiro / Rodrigo Banha da Silva / Francisca Alves Cardoso

\section{9. Época Moderna e Contemporânea}

1721 Arqueologia Moderna em Portugal: algumas reflexões críticas em torno da quantificação de conjuntos cerâmicos e suas inferências históricas e antropológicas Rodrigo Banha da Silva / André Bargão / Sara da Cruz Ferreira

1733 Faianças de dois contextos entre os finais do século XVI e XVIII do Palácio dos Condes de Penafiel, Lisboa

Martim Lopes / Tomás Mesquita 
1747 Um perfil de consumo do século XVIII na foz do Tejo: O caso do Mercado da Ribeira, Lisboa Sara da Cruz Ferreira / Rodrigo Banha da Silva / André Bargão

1761 Os Cachimbos dos Séculos XVII e XVIII do Palácio Mesquitela e Convento dos Inglesinhos (Lisboa)

Inês Simão / Marina Pinto / João Pimenta / Sara da Cruz Ferreira / André Bargão / Rodrigo Banha da Silva

1775 "Tomar os fumos da erua que chamão em Portugal erua sancta». Estudo de Cachimbos provenientes da Rua do Terreiro do Trigo, Lisboa

Miguel Martins de Sousa / José Pedro Henriques / Vanessa Galiza Filipe

1787 Cachimbos de Barro Caulínitico da Sé da Cidade Velha (República de Cabo Verde)

Rodrigo Banha da Silva / João Pimenta / Clementino Amaro

1801 Algumas considerações sobre espólio não cerâmico recuperado no Largo de Jesus (Lisboa) Carlos Boavida

1815 Adereços de vidro, dos séculos XVI-XVIII, procedentes do antigo Convento de Santana de Lisboa (anéis, braceletes e contas)

Joana Gonçalves / Rosa Varela Gomes / Mário Varela Gomes

1837 Da ostentação, luxo e poder à simplicidade do uso quotidiano: arqueologia e simbologia de joias e adornos da Idade Moderna Portuguesa Jéssica Iglésias

1849 Os amuletos em Portugal - dos objetos às superstições: o coral vermelho Alexandra Vieira

1865 Cerâmicas de Vila Franca de Xira nos séculos XV e XVI Eva Pires

1879 «Não passa por teu o que me pertence». Marcas de individualização associadas a faianças do Convento de Nossa Senhora de Aracoeli, Alcácer do Sal Catarina Parreira / Íris Fragoso / Miguel Martins de Sousa

1891 Cerâmica de Leiria: alguns focos de produção

Jaqueline Pereira / André Donas-Botto

1901 Os Fornos na Rua da Biquinha, em Óbidos Hugo Silva / Filipe Oliveira

1909 A casa de Pêro Fernandes, contador dos contos de D. Manuel I: o sítio arqueológico da Silha do Alferes, Seixal (século XVI) Mariana Nunes Ferreira

1921 O Alto da Vigia (Sintra) e a vigilância e defesa da costa Alexandre Gonçalves / Sandra Santos

1937 O contexto da torre sineira da Igreja de Santa Maria de Loures Paulo Calaveira / Martim Lopes

1949 A Necrópole do Hospital Militar do Castelo de São Jorge e as práticas funerárias na Lisboa de Época Moderna Susana Henriques / Liliana Matias de Carvalho / Ana Amarante / Sofia N. Wasterlain

1963 SAND - Sarilhos Grandes Entre dois Mundos: o adro da Igreja e a Paleobiologia dos ossos humanos recuperados

Paula Alves Pereira / Roger Lee Jesus / Bruno M. Magalhães

1975 Expansão urbana da vila de Cascais no século XVII e XVIII: a intervenção arqueológica na Rua da Vitória no 15 a 17

Tiago Pereira / Vanessa Filipe

1987 Novos dados para o conhecimento do Urbanismo de Faro em época Moderna Ana Rosa 
1995 Um exemplo de Arqueologia Urbana em Alcoutim: o Antigo Edifício dos CTT Marco Fernandes / Marta Dias / Alexandra Gradim / Virgílio Lopes / Susana Gómez Martínez

2007 Palácio dos Ferrazes (Rua das Flores/Rua da Vitória, Porto): a cocheira de Domingos Oliveira Maia

Francisco Raimundo

2021 As muitas vidas de um edifício urbano: História, Arqueologia e Antropologia no antigo Recreatório Paroquial de Penafiel Helena Bernardo / Jorge Sampaio / Marta Borges

2035 O convento de Nossa Senhora da Esperança de Ponta Delgada: o contributo da arqueologia para o conhecimento de um monumento identitário João Gonçalves Araújo / N’Zinga Oliveira

2047 Arqueologia na ilha do Corvo... em busca da capela de Nossa Senhora do Rosário Tânia Manuel Casimiro / José Luís Neto / Luís Borges / Pedro Parreira

2059 Perdidos à vista da Costa. Trabalhos arqueológicos subaquáticos na Barra do Tejo Jorge Freire / José Bettencourt / Augusto Salgado

2071 Arqueologia marítima em Cabo Verde: enquadramento e primeiros resultados do projecto CONCHA

José Bettencourt / Adilson Dias / Carlos Lima / Christelle Chouzenoux / Cristóvão Fonseca / Dúnia Pereira / Gonçalo Lopes / Inês Coelho / Jaylson Monteiro / José Lima / Maria Eugénia Alves / Patrícia Carvalho / Tiago Silva

2085 Trabalhos arqueológicos na Cidade Velha (Ribeira Grande de Santiago, Cabo Verde): reflexões sobre um projecto de investigação e divulgação patrimonial André Teixeira / Jaylson Monteiro / Mariana Mateus / Nireide Tavares / Cristovão Fonseca / Gonçalo C. Lopes / Joana Bento Torres / Dúnia Pereira / André Bargão / Aurélie Mayer / Bruno Zélie / Carlos Lima / Christelle Chouzenoux / Inês Henriques / Inês Pinto Coelho / José Lima / Patrícia Carvalho / Tiago Silva

2103 A antiga fortificação de Quelba / Khor Kalba (E.A.U.). Resultados de quatro campanhas de escavações, problemáticas e perspectivas futuras Rui Carita / Rosa Varela Gomes / Mário Varela Gomes / Kamyar Kamyad

2123 Colónias para homens novos: arqueologia da colonização agrária fascista no noroeste ibérico Xurxo Ayán Vila / José Mạ . Señorán Martín 


\title{
ARQUEOLOGIA MARÍTIMA EM CABO VERDE: ENQUADRAMENTO E PRIMEIROS RESULTADOS DO PROJECTO CONCHA
}

José Bettencourt ${ }^{1}$, Adilson Dias ${ }^{2}$, Carlos Lima ${ }^{3}$, Christelle Chouzenoux ${ }^{4}$, Cristóvão Fonseca ${ }^{5}$, Dúnia Pereira ${ }^{6}$, Gonçalo Lopes $^{7}$, Inês Coelho ${ }^{8}$, Jaylson Monteiro ${ }^{9}$, José Lima ${ }^{10}$, Maria Eugénia Alves ${ }^{11}$, Patrícia Carvalho ${ }^{12}$, Tiago Silva ${ }^{13}$

\section{RESUMO}

Entre os parceiros da Cátedra UNESCO O Património Cultural dos Oceanos contam-se o CHAM e o Instituto do Património Cultural de Cabo Verde, que definiram como tarefa essencial a carta arqueológica subaquática daquele arquipélago. Esta acção iniciou-se em 2018 no âmbito do projecto Europeu CONCHA, que tem como objectivo analisar o desenvolvimento das cidades portuárias no Atlântico durante a época moderna.

As missões do CONCHA realizaram-se na ilha de Santiago, no fundeadouro da Ribeira Grande, no naufrágio de São Francisco (século XVII) e no Urânia (1809). Incluíram o mapeamento e a revisão de documentação e dos materiais arqueológicos destes sítios, em depósito no Museu de Arqueologia. Foram igualmente desenvolvidas actividades de divulgação e acções de formação. Esta comunicação sistematiza os resultados destes trabalhos. Palavras-chave: Arqueologia Marítima, Arqueologia Moderna, Atlântico, Cabo Verde.

\begin{abstract}
Among the partners of the UNESCO Chair The Ocean's Cultural Heritage are CHAM and IPC (Cape Verde) which defined as essential action the underwater archaeological site inventory of that archipelago. This action started in 2018 as part of the European project CONCHA, that aims to address the different ways that port cities developed around the Atlantic during the early modern era.

CONCHA's surveys were conducted on the island of Santiago, in Ribeira Grande anchorage, in São Francisco ( $17^{\text {th }}$ century) and in Urânia shipwrecks (1809). The project included the underwater survey, a review of the documentation and of the archaeological materials, recovered from the sites, at the Museum of Archaeology in Praia. Dissemination and training activities were also carried out. This paper systematizes the results of these works. Keywords: Maritime Archeology, Early Modern Archeology, Atlantic, Cape Verde.
\end{abstract}

\footnotetext{
1. CHAM - Centro de Humanidades e FCSH, Universidade Nova de Lisboa; jbettencourt.cham@gmail.com 2. Instituto do Património Cultural de Cabo Verde (IPC); didias386@gmail.com

3. Instituto do Património Cultural de Cabo Verde (IPC); conser-rest.lima@ootlook.com

4. EVEHA; krist_aile@yahoo.fr

5. CHAM - Centro de Humanidades; cristovaofonseca@gmail.com

6. Instituto do Património Cultural de Cabo Verde (IPC); duniapereira79@gmail.com

7. CHAM - Centro de Humanidades; goncaloncsl@gmail.com

8. CHAM - Centro de Humanidades; inesalexandrapinto@gmail.com

9. Instituto do Património Cultural de Cabo Verde (IPC); Jaylson.Monteiro@iipc.gov.cv

10. Instituto do Património Cultural de Cabo Verde (IPC); joselima1995@hotmail.com

11. Instituto do Património Cultural de Cabo Verde (IPC); eugenialves9@hotmail.com

12. CHAM - Centro de Humanidades; patriciasanchescarvalho@gmail.com

13. CHAM - Centro de Humanidades; toiago@gmail.com
} 


\section{INTRODUÇÃO}

Cidades Globais; Redes; Oceano Atlântico; Património Cultural são as palavras chave por detrás do projecto CONCHA: The construction of early modern global Cities and oceanic networks in the Atlantic: An approach via Ocean's Cultural Heritage. O projecto resulta de uma rede de contactos e parcerias estabelecidas no âmbito da Cátedra UNESCO O Património Cultural dos Oceanos e pretende abordar as diferentes formas pelas quais se desenvolveram as cidades portuárias nas margens do Atlântico, entre o final do século XV e início do XVIII. Liderado pela Universidade NOVA de Lisboa, e sedeado no CHAM, o projecto reúne 11 parceiros internacionais de entidades académicas e não-académicas: Associação para as Ciências do Mar (APCM), Observatório do Mar dos Açores (OMA), Universidad Pablo de Olavide (UPO), Trinity College Dublin (TCD), EVEHA, Instituto de Património Cultural (IPC), Universidad del Norte (UniNorte), MARAPA, Mar Ambiente e Pesca Artesanal, Universidade Federal de Sergipe (UFS) e Old Dominiom University (ODU). É financiado ao abrigo do Programa H2O2O, no âmbito das acções Marie Slodowska Curie Actions: Research and Inovation Staff Exchange (RISE).

Com relações já estabelecidas pelo envolvimento na Cátedra UNESCO O Património Cultural dos Oceanos, os parceiros CHAM e IPC definiram como área prioritária de intervenção o estudo e a valorização do Património Cultural Subaquático (PCS) de Cabo Verde, nomeadamente através do desenvolvimento da carta arqueológica subaquática do arquipélago. As primeiras missões arqueológicas deste programa realizaram-se na ilha de Santiago ao abrigo do projecto CONCHA. Focaram-se no fundeadouro da Ribeira Grande (Cidade Velha), uma das primeiras ocupações europeias na África subsariana, porto fundamental no comércio de escravos no Atlântico e Património Mundial da UNESCO desde 2009. Além da Cidade Velha, foram selecionados mais dois sítios arqueológicos relevantes para o conhecimento da importância do arquipélago nas redes de circulação atlântica: o naufrágio de São Francisco, o mais antigo conhecido até à data no arquipélago, e o naufrágio da fragata portuguesa Urânia, perdida em frente à Cidade da Praia (Smith 2002; D’Oliveira 2005, pp. 9o91; Fig. 1) (Figura 1).

O trabalho foi desenvolvido faseadamente, em três campanhas de terreno, entre Abril de 2018 e Feve- reiro de 2019, que contaram com a participação dos técnicos do IPC, dos investigadores do CHAM, dos parceiros franceses da empresa EVEHA, e também com a colaboração de Emanuel Charles de Oliveira e de Alexandre Semedo.

Estas missões centraram-se na avaliação do potencial científico dos sítios arqueológicos e consistiram na georreferenciação e no registo dos contextos em mergulho. Foi também efectuada uma revisão da documentação e dos materiais arqueológicos provenientes destes sítios, actividades de divulgação para o público escolar e acções de formação. Neste artigo apresentam-se os principais resultados obtidos.

\section{ENQUADRAMENTO}

A história de Cabo Verde, do seu povoamento e desenvolvimento, está intimamente ligada ao mar. A sua posição geográfica privilegiada tornou as ilhas em plataformas de apoio logístico às rotas transoceânicas, ponto de passagem quase obrigatório, tanto para os navios da Coroa Portuguesa, como das restantes monarquias europeias que demandavam os mares do Sul. Numa primeira fase, o seu principal porto, Ribeira Grande de Santiago, era apenas ponto de passagem e abastecimento, mas no final da primeira década após o seu descobrimento este ganhou uma nova ordem, passando a residência dos principais comerciantes e local de produção de bens para trocas comerciais nos Rios da Guiné. A Ribeira Grande, um dos primeiros burgos edificados por portugueses na África subsariana, transformou-se num importante entreposto comercial ligado ao tráfego negreiro, obtendo foro de Cidade e estatuto de Bispado em 1533, o primeiro de África, com jurisdição evangélica nos chamados 'Rios de Guiné", no Continente fronteiro (Torrão e Teixeira, 2009).

A importância económica e estratégica de Cabo Verde, que marcou a história do arquipélago, legou também um património subaquático de valor inestimável, que pela sua variedade e proveniência diversa representa a primeira globalização. O número de navios afundados na orla marítima cabo-verdiana está ainda por apurar, mas estudos preliminares referenciam já mais de uma centena de naufrágios, a maioria localizados ao largo da Boa Vista, Maio e Santiago, perdidos quando passavam entre as ilhas ou faziam escalas de apoio, com origens muito diversas (D’Oliveira, 2005, pp.138-156).

O interesse por estes vestígios revelou-se cedo, ainda 
antes da independência, contando-se mais de uma dezena de iniciativas. Deste período resultou pouca informação sobre os contextos intervencionados, as recuperações efectuadas e o respectivo destino dos materiais exumados, mas as notícias na imprensa eram comuns (D'Oliveira, 2005, pp. 137-139).

O interesse por este património subaquático regressou após a independência. O Estado Cabo-verdiano passou a ser frequentemente assediado, com propostas de pesquisa em várias ilhas, algumas de exploradores célebres em salvados em vários países. Em 1980, Robert Marx fez um pedido para localizar uma embarcação fenícia. No mesmo ano, Robert Sténuit propõe recuperar objectos de dois naufrágios específicos, um do reinado de Luís XIV e outro da Companhia Holandesa das Índias Orientais (VOC), missões que não se chegaram a realizar ( $\mathrm{D}^{\prime}$ 'Oliveira, 2005, p. 139). Nos anos seguintes continuaram a surgir propostas, entre as quais a World Wide First, em 1984, representada por Franck Goddio e Edmound Balm, que se comprometia a formar um conservador e dois mergulhadores locais, o que também não chegou a acontecer. Na mesma altura, foi negociado um possível contrato com Erick Surcouf, onde estavam definidos parâmetros como a repartição do material recuperado, as despesas de execução dos trabalhos e as contrapartidas para o governo de Cabo Verde, que incluíam mais uma vez a formação de um conservador ou dois mergulhadores.

A exploração há muito adiada acabaria por ser efetivada na década de 1990, altura em que o Estado empreendeu um conjunto de missões de "salvamento de espólio subaquático" e de escavações arqueológicas terrestres. Para a vertente subaquática, o Estado de Cabo Verde assinou, inicialmente, em 1992, um contrato com a empresa sul-africana Afrimar, que concentrou as suas ações na ilha da Boa Vista, nos naufrágios do Hartwell, Santo André e Leimuiden. Em 1995, o Estado assinou outro contrato de exploração com a Empresa Arqueonautas South Atlantic, posteriormente Arqueonautas World Wide, S.A. Entre 1995 e 2001, esta empresa portuguesa, sediada na ilha da Madeira, deu continuidade ao trabalho da Afrimar, alargado a outras ilhas. De acordo com os dados disponíveis na documentação em depósito no IPC, foram identificados 71 sítios subaquáticos e terão sido escavados 11 naufrágios e duas zonas na Cidade Velha.

Apesar da quase ausência de publicações, o legado desta exploração teve impacto na arqueologia cabo- -verdiana, dando origem ao Museu de Arqueologia, à formação de técnicos de conservação e a uma maior exigência no tratamento do PCS do arquipélago. Esse caminho viria a ser iniciado ainda durante o trabalho de campo. O acordo entre a Arqueonautas e Cabo Verde previa a cedência de um edifício na zona portuária da Praia, ocupado em Dezembro de 1998, com o início da instalação da equipa técnica e administrativa que viria a garantir o apoio às intervenções de terreno. Depois de algumas obras de adaptação realizadas no edifício, este recebeu a denominação de Centro de Conservação e Restauro, sendo aí instalada uma equipa de técnicos estrangeiros e nacionais contratados pela empresa para apoio aos trabalhos de campo. Posteriormente, este espaço passou a ser denominado Centro de Restauro e Museologia (CRM). A introdução de estantes e prateleiras numa das salas para acondicionamento dos objetos conservados levou à sua exibição, por forma a serem usufruídos pelos visitantes que afluíam a esse espaço em número crescente, quer em delegações oficiais (inclusive a Delegação da Presidência da República de Cabo Verde, chefiada pelo então Presidente Pedro Verona Pires; Membros do Conselho de Ministros e Delegações Estrangeiras), quer em visitas casuais de curiosos.

Por conseguinte, nota-se a introdução da vertente museológica numa instalação cuja vocação inicial era acolher os objetos, conservá-los, documentá-los e armazená-los, para no final se fazer a partilha, conforme estipulado no contrato de concessão firmado entre a empresa e o Estado de Cabo Verde.

O Museu de Arqueologia nasce neste contexto, materializando assim a recomendação do Grupo de Trabalho sobre Pesquisas Arqueológicas que nos anos 8 o já tinha acautelado o princípio de dar a conhecer o acervo arqueológico resultante dos trabalhos de pesquisa e escavações subaquáticas, a serem realizadas, quando afirma que "As operações podem conduzir à recolha de um $\mathrm{n}^{\circ}$. apreciável de objectos com valor histórico que justifique um local para sua guarda e exposição." (Cardoso, 1984, p. 5).

A partir de 2002, altura em que se efetuou a partilha dos objetos, o então IIPC decidiu trabalhar no sentido de divulgar o acervo arqueológico que Cabo Verde conseguiu obter com a intervenção das empresas. Depois dos trabalhos de adequação do edifício, o Núcleo Museológico da Praia foi inaugurado em Dezembro de 2005, com a exposição denominada de "Nos Patrimoniu". Foi o materializar da vontade 
do IIPC em divulgar e promover o património arqueológico do país, com o objetivo de sensibilizar as pessoas para a questão da preservação e valorização dos bens culturais.

Esta exposição tinha duas vertentes: uma arqueológica e outra etnográfica. $\mathrm{O}$ facto de se reunir numa mesma exposição testemunhos de proveniências disciplinares diferentes justificava-se porque, nessa altura, o Museu Etnográfico da Praia estava a ser encerrado, para receber obras de beneficiação do edifício, algo que aconteceu nos finais de 2005 e princípios de 2006. Terminadas as obras no Museu Etnográfico da Praia, todo o espólio em exposição foi devolvido à origem, ficando no Núcleo Museológico da Praia apenas objetos relativos ao património arqueológico. Em 2007, com o apoio financeiro da Embaixada dos Estados Unidos da América, o então IIPC fez obras no edifício, melhorando a qualidade das instalações, transformando-o naquilo que é hoje o Museu de Arqueologia, inaugurado no dia 24 de Outubro de 2008. O Museu de Arqueologia é de tutela e gestão estatal (IIPC), de âmbito nacional e temática disciplinar, com um acervo testemunho da importância histórica de Cabo Verde entre os séculos XV e XIX. Tem como principal missão a preservação e divulgação do património arqueológico do país, nas suas várias vertentes subaquática e terrestre, visando alcançar o público em geral, e em particular os investigadores, professores e alunos dos vários níveis de ensino.

O espólio à sua guarda inclui o resultado dos trabalhos subaquáticos da década de 1990. Proveniente de várias paragens e, chegado a Cabo Verde em embarcações com bandeira das principais potências marítimas europeias (Espanha, Portugal, Inglaterra, Holanda e França) e dos Estado Unidos da América, enquanto principal patrulheiro do atlântico na luta contra o tráfico ilegal de escravos, o espólio mostra a diversidade e riqueza do conteúdo imaterial associado a cada artefacto. As coleções são diversas, incluindo instrumentos de navegação, elementos da estrutura e equipamento de navios, armamento, vestígios de cargas - que incluem presas em marfim, moedas, correntes e algemas, faunas, cerâmicas -, para além de artefactos que representam a vida a bordo das embarcações, incluindo, por exemplo, utensílios de cozinha e objectos de uso pessoal. Inclui-se também extensa documentação sobre os trabalhos efectuados.

O Museu guarda igualmente um importante legado patrimonial fruto das escavações terrestres, constituído por objetos provenientes da Cidade Velha (Ribeira Grande de Santiago), Trindade (Praia), Alcatraz (São Domingos), Igreja de Santiago Maior (Santa Cruz), Concheiro de Salamansa (São Vicente) e Forte da Preguiça (S. Nicolau). São particularmente relevantes os vestígios dos primeiros assentamentos humanos na Cidade Velha, na Trindade e na Baía de Alcatraz - Nossa Senhora da Luz, que documentam o modo de vida, social, cultural e religioso, dos primeiros colonizadores.

Além do material em reserva, o Museu de Arqueologia apresentou o espólio proveniente da exploração de sítios subaquáticos em duas exposições na última década, mantendo também uma parte exposta no Museu do Mar, no Mindelo, e no Museu do Sal, em Santa Maria.

A actual exposição, na Praia, intitulada de "Hi(é)stórias que o nosso Mar Preservou", foi inaugurada em 2018 e assume uma estrutura temática, que parte da apresentação de materiais de acordo com a sua utilidade nos navios. A visita é iniciada com objetos e equipamentos associados à navegação e aos navios, seguindo-se uma amostra de marfim da carga do naufrágio Princess Louise e por vitrines onde se encontram jóias, relógios e objetos associados à beleza moedas de vários países e outros objetos utilizados em trocas comerciais, e ainda materiais que documentam a vida a bordo. A exposição termina com a colecção de equipamentos bélicos e com uma apresentação multimédia com conteúdos sobre a coleção do Museu de Arqueologia. O Museu dispõe ainda de uma vitrine temporária intitulada "Uma Questão de Escala", montada em parceria entre o IPC e o projecto CONCHA, que conjuga a Arqueologia e a História Ambiental Marinha.

\section{AS MISSÕES DO CONCHA}

3.1. O inventário dos materiais e da documentação Além de trabalho de campo, a avaliação dos sítios intervencionados durante o projecto foi realizada através da consulta de processos e do estudo de uma amostra dos materiais depositados no Museu de Arqueologia da Praia.

$\mathrm{O}$ arquivo da arqueologia de Cabo Verde corresponde a várias pastas com documentação administrativa e fotocópias de fichas de conservação dos materiais recuperados nos vários sítios intervencionados pela empresa Arqueonautas. Esta documentação inclui o 
historial das intervenções, bem como alguns processos relativos às vendas em leilão dos artefactos mais valiosos; documentos sobre a organização das várias missões, equipas de trabalho ou contratos firmados entre o Governo de Cabo Verde e vários intervenientes. Foi igualmente consultada documentação em papel recentemente entregue pela Arqueonautas ao IPC, em trânsito em Lisboa, onde se encontram fichas de mergulho, plantas ou inventários dos materiais recuperados nos vários contextos, além de dados históricos sobre naufrágios.

Esta informação, em grande parte duplicada, foi tratada em dois momentos distintos, de modo a reunir um arquivo digital o mais completo possível: num primeiro, foram fotografadas a totalidade das páginas de cada dossier no Museu da Praia; num segundo, em Lisboa, a documentação em trânsito foi digitalizada.

A análise dos materiais em depósito no Museu de Arqueologia foi restringida ao espólio proveniente dos sítios intervencionados no âmbito do CONCHA. A selecção procurou ser o mais representativa possível das colecções, correspondendo a uma amostra dos diferentes materiais recuperados (cerâmica comum e vidrada, faiança, vidro, materiais em liga de estanho e de cobre), que foram inventariados, fotografados e desenhados. Algumas peças de maior dimensão, nomeadamente as botijas que se encontravam completas, foram registadas através de fotogrametria, base para o posterior desenho.

\subsection{Os trabalhos subaquáticos}

Foram avaliados em mergulho o fundeadouro da Cidade Velha e os sítios subaquáticos de naufrágio de São Francisco e do Urânia, todos na ilha de Santiago (Figura 1). Além da observação e documentação em vídeo e fotografia, o registo incluiu o levantamento fotogramétrico dos contextos e das áreas com maior potencial arqueológico.

Os trabalhos de prospecção efectuados no fundeadouro da Cidade Velha, em frente ao centro histórico, permitiram confirmar o seu potencial científico e patrimonial. A zona corresponde a um fundo de areia e cascalho, encaixada entre duas plataformas rochosas, onde a profundidade evolui rapidamente, atingindo os $25 \mathrm{~m}$ apenas a $400 \mathrm{~m}$ da praia. A área arenosa, com boas condições de ancoragem, atinge aproximadamente $80 \mathrm{~m}$ de largura, terminando abruptamente a leste e oeste em plataformas rochosas constituídas por escoadas vulcânicas, limitando e dificultando, por isso, as condições de operação dos navios (Figura 2).

O registo material da utilização portuária da baía em frente à Ribeira Grande surge sobretudo a partir dos $17 \mathrm{~m}$ de profundidade. Os vestígios arqueológicos incluem numerosas âncoras em ferro, de dimensões, tipologias e cronologias distintas, depositadas na zona de areia, mas também nas plataformas rochosas que a limitam, além de cerâmicas, também de várias tipologias, distribuídas por todo o espaço prospetado, mas com maior densidade algumas áreas.

As cerâmicas incluem diversas produções, mas abundam sobretudo os bordos e paredes de botijas e outros fabricos claramente peninsulares: formas quotidianas em cerâmica comum vermelha, formas de açúcar, louça esmaltada a branco sem decoração e cerâmica vidrada.

Estes materiais são idênticos a outros depositados no Museu de Arqueologia da Praia recuperados pela empresa Arqueonautas. Esta colecção é na verdade vasta e heterógena, com origens distintas, mas com uma cronologia que abarca principalmente os séculos XVI e XVII, com presença maior de produções peninsulares. Destacam-se as mesmas tipologias documentadas durante os nossos trabalhos - botijas, formas de açúcar, cerâmica esmaltada a branco sem decoração ou cerâmica vermelha. As botijas, por exemplo, de diversas tipologias, são sobretudo de fabrico andaluz, origem que pode ser também atribuída a, pelo menos, uma forma de açúcar em exposição no Museu (Amores Carredano e Chisvert Jiménez, 1993, p. 278; Fig. 3). A mesma proveniência poderá ser conferida a pratos e escudelas esmaltadas a branco, também frequentes. Em menor quantidade, surgem produções andaluzas com decoração, cerâmicas vidradas a verde ou melado, várias tipologias de cerâmica vermelha sem decoração, faiança portuguesa, cachimbos do noroeste europeu, algumas porcelanas chinesas, majólicas italianas e cerâmicas de origem africana (Figura 4). A colecção proveniente do fundeadouro da Cidade Velha inclui também algumas peças metálicas, nomeadamente bocas-de-fogo e manilhas (Figura 3).

Os trabalhos permitiram igualmente localizar três possíveis contextos de naufrágio na Cidade Velha. $\mathrm{Na}$ zona de areia foram documentados os restos de um navio em madeira ( $\mathrm{CV}_{1}$; Figura 5). Os outros prováveis contextos de naufrágio correspondem a conjuntos de canhões. No primeiro, localizado junto aos ilhéus, estão documentados três canhões em 
ferro, cuja origem é difícil de determinar, embora o arquivo da empresa Arqueonautas refira a recuperação ali de materiais durante sondagens, nomeadamente balas em chumbo (AGO-050). O segundo $\left(\mathrm{CV}_{2}\right)$ corresponde a um claro contexto de naufrágio, situado a sudoeste da Ponta Grande da Cidade, com 13 canhões em ferro, depositados numa depressão ao longo de $29 \mathrm{~m}$. A cronologia é em ambos difícil de determinar nesta fase.

A segunda área de intervenção corresponde ao naufrágio de São Francisco, localizado em Passa Pau, numa costa rochosa, exposta e de difícil acesso. Apesar das dificuldades, a intervenção em Passa Pau justificava-se pela importância histórica e simbólica que este naufrágio encerra. Intensamente explorado pela empresa Arqueonautas, é o mais antigo até à data identificado em Cabo Verde. Dali foi recuperado um raro astrolábio, na origem de uma das poucas publicações sobre a intervenção daquela empresa no arquipélago (Smith, 2002). Actualmente no The Mariners' Museum and Park, nos Estados Unidos, é uma peça banhada a prata que terá sido fabricada por Nicolao Rvffo em 1645, terminus post quem para a constituição do contexto, que inclui também uma diversificada colecção de materiais, metálicos e cerâmicos, globalmente atribuíveis à segunda metade do século XVII.

Os trabalhos ali efectuados permitiram verificar que os contextos deste naufrágio se encontram num fundo muito irregular, que varia entre afloramentos rochosos, que emergem à superfície nalgumas áreas, formando caneiros perpendiculares à costa. Os restos encontram-se concentrados ao longo de aproximadamente $30 \mathrm{~m}$, sobretudo num desses caneiros, mas a dispersão dos materiais estende-se a depressões periféricas. Actualmente os vestígios dominantes correspondem a 17 canhões em ferro e três âncoras no mesmo material.

Além destas peças em ferro, observaram-se vários materiais de superfície, nomeadamente numerosos fragmentos de cerâmica, tendo sido recuperados um bordo de botija (SFig-oor) e um bordo de talha (SF19-O02). Estes materiais são semelhantes aos recuperados em Passa Pau pela empresa Arqueonautas (Figura 6). Nesta colecção contam-se, pelo menos, meia centena de bordos com a mesma morfologia do SFi9-oor, com possível fabrico andaluz. A talha SFig-oo2 também encontra paralelo nos materiais no Museu, sendo provavelmente da mesma área de produção que as botijas (Amores Carredano e Chisvert Jiménez, 1993, p. 276 e 301). A origem Andaluza também pode ser atribuída às cerâmicas esmaltadas a branco sem decoração proveniente do mesmo contexto, embora também tenham surgido vários fragmentos de cachimbos em grés de fabrico do noroeste europeu e pelo menos dois fornilhos de tradição africana.

Além das cerâmicas, o Museu de Arqueologia guarda um vasto espólio do naufrágio de São Francisco, incluindo um número elevado de moedas em prata, pratos em estanho, sondas, balas e placas em chumbo, um compasso de navegação, um crucifixo e um candelabro em liga de cobre. Neste último metal destaca-se um conjunto de escudelas encontradas empilhadas. Em estanho é particularmente relevante a extensa colecção de tampas de garrafas quadradas em vidro, com diversas tipologias. Destaque também para uma manilha recta e um eixo, provavelmente de uma ou mais grilhetas, com claras semelhanças, na forma e nas dimensões, às encontradas no sítio de perda do navio negreiro inglês Henrietta Marie, que naufragou em Marquesas Keys, Golfo do México, em 1700 (Moore e Malcom, 2008, p. 28).

A grilheta, a par da presença de elementos africanos no contexto, atribui particular relevância ao naufrágio de São Francisco. Além de ser o mais antigo conhecido em Cabo Verde, esta assinatura material coloca-nos na pista das rotas negreiras. A predominância de moedas espanholas e de cerâmicas andaluzas sugere corresponder a um navio espanhol em rota para Cabo Verde, algures na segunda metade do século XVII (com grande probabilidade no terceiro quartel), possivelmente para adquirir escravos.

O último sítio intervencionado corresponde ao único do qual se conhece com segurança a identidade. A fragata Urânia naufragou na cidade da Praia a 5 de Fevereiro de 1809, quando voltava ao Brasil depois de uma escolta a Inglaterra. Lançada à água a 15 de Dezembro de 1792 com o nome Ulisses, que manteve até 1807 , esta fragata da Marinha Portuguesa tinha 132 pés de comprimento $(43,56 \mathrm{~m}), 34$ de boca (11,22 m) e 25 de pontal $(8,25 \mathrm{~m})$ e armava entre $32 \mathrm{e}$ 36 peças. A tripulação rondava os 300 homens, entre oficiais, cozinheiros, marinhagem e guarnições. Ao longo da sua carreira efectuou diversas missões no Canal da Mancha, Argel, Açores, Inglaterra, Tânger, ou Brasil, tendo, por exemplo, integrado a esquadra que retirou a família Real para o Brasil em Novembro de 1807 (Esparteiro, 1979, p. 87-99). Os vestígios atribuídos ao Urânia encontram-se 
aproximadamente a sul do Ilhéu da Praia, ocupando um fundo essencialmente rochoso, de afloramentos e grandes blocos. O contexto é dominado por canhões em ferro dispersos e por uma extensa concreção constituída por canhões e barras no mesmo metal, ao longo de $41 \mathrm{~m}$ (Figura 7). A distribuição dos materiais sugere que o tumulus corresponde sensivelmente à posição do fundo do casco, ao lastro depositado no porão do navio, constituído por canhões e barras em ferro, e a um paiol de pelouros, onde estavam armazenadas balas no mesmo metal. Os canhões alinhados a oeste deverão corresponder ao local de deposição final de parte das peças de uma das baterias do navio. As outras terão sido recuperadas após o naufrágio, o mesmo acontecendo com as âncoras e outros equipamentos.

Os vestígios móveis de pequenas dimensões ainda existentes no sítio são escassos, tendo apenas sido observados alguns fragmentos de pregaduras e chapas em liga de cobre. O Museu de Arqueologia da Praia guarda, no entanto, uma pequena colecção constituída sobretudo por objectos metálicos. Entre estes, encontram-se uma das fêmeas do leme, vários fragmentos de pregos e chumaceiras em ligas de cobre. Destaque igualmente para um botão com as armas da Marinha Portuguesa, de um almofariz, ambos em liga de cobre, ou de um prato e um jarro, em estanho. Foram também recuperados alguns fragmentos de cerâmicas e vidros.

\subsection{Divulgação e actividades educativas}

Os Museus, espaços culturais por excelência de preservação da nossa história coletiva, onde a educação e o lazer são primordiais para a disseminação e democratização do conhecimento, devem privilegiar a relação de proximidade com o público e a sua comunicação deter a capacidade de formar/ informar, desenvolver competências e promover mudanças de atitude para quem visita a Instituição (Assiz, 2017, p. 19).

Nesta perspetiva, o Museu de Arqueologia da cidade da Praia, uma instituição de âmbito nacional e de tutela estatal, tem responsabilidades acrescidas no que toca a divulgação do património. Tendo isso em consideração, disponibiliza, através das suas exposições permanentes e temporárias, visitas orientadas, publicações, acções educativas e de disseminação, atividades socioeducativas, colónias de férias ou oficinas, entre outras atividades, como forma de comunicar o seu acervo e atingir vários públicos. Por se caracterizar como um espaço de memória e de salvaguarda do património nacional cabo-verdiano, é um lugar ideal para se realizar actividades tendentes à dinamização e divulgação da riqueza do espólio cultural subaquático e terrestre, figurando-se também como um espaço de lazer e consolidação do conhecimento científico.

Por conseguinte, no seguimento das acções de divulgação, sensibilização e educativas já programadas, em 2018 o Museu definiu redinamizar a actividade "Arqueólogo por um dia", em parceria com o CONCHA, introduzindo a vertente subaquática (Figura 8). Esta iniciativa teve como público-alvo os estudantes de vários níveis de ensino e consistiu numa introdução à Ciência Arqueologia, iniciando os participantes no processo de investigação arqueológica, com enfoque nas simulações de escavações subaquáticas e terrestres. Tendo em conta a aceitação positiva por parte do público/visitantes, a acção, inicialmente com a participação dos investigadores do CONCHA, continua actualmente, materializada pelos técnicos nacionais do Museu de Arqueologia. Foi igualmente efectuado um workshop de introdução à arqueologia subaquática, onde participaram técnicos de várias entidades cabo-verdianas, incluindo a Polícia Marítima e a Guarda Costeira, e representantes de centros de mergulho da ilha de Santiago. A divulgação dos trabalhos foi assegurada através das redes sociais, partindo da publicação de notícias na página do Facebook do IPC, e teve cobertura pela imprensa escrita e televisiva.

\subsection{A conservação do material recuperado}

O projeto CONCHA tem proporcionado ao Museu de Arqueologia a realização de algumas ações de conservação curativa de materiais recuperados durante as missões de terreno de 2018 e 2019, tanto em contextos subaquáticos, como terrestres. $\mathrm{O}$ tratamento dos artefactos teve como objetivo principal estabilizar o seu estado de conservação, garantindo a sua preservação para as gerações atuais e vindouras, em condições que permitam a sua apresentação e utilização em acções de educação patrimonial, nas comunidades, escolas, universidades, e em estudos científicos. Os materiais deram entrada no Museu submergidos em água salgada, para evitar a secagem brusca, evitando a sua deterioração. Esta medida é o primeiro passo na conservação dos artefactos de contextos submarinos, sendo recomendada para todos os materiais. Estes passaram depois por uma processo 
de dessalinização, sendo mantidos em tanques com água doce com $\mathrm{pH}$ ajustado, substituída e controlada progressivamente até que os componentes químicos ( $\mathrm{NaCl}$ - cloreto de sódio) do material estejam estabilizados.

Este procedimento foi realizado em todos os artefactos recuperados. Estes foram depois documentados, começando com a guia de entrada de objetos no Museu, seguido de um registo fotográfico com detalhes do objeto em diferentes perspetivas, fases anteriores a outras acções específicas necessárias.

Entre estas acções encontra-se uma análise óptica, com lupa, a fim de avaliar o estado físico, as incrustações calcárias marinhas e outros resíduos associados. Verificou-se que as peças apresentavam alterações resultantes da colonização e do crescimento de bactérias e algas sobre as superfícies enquanto submersas. Entre os itens encontrados, refiram-se as clorofíceas, também chamadas algas verdes, a Fissurella, que é um género de pequenos e médios caracóis (lapas) marinhos da família Fissurellidae com entre $8 \mathrm{~mm}$ a $1 \mathrm{~cm}$. Refira-se também os cerca de 21 gramas de areia multicolor, devida à contaminação de metais ferrosos, minerais e algas, e uma ligeira fissura numa das extremidades do alguidar CV18-oo1, recuperado no fundeadouro da Ribeira Grande de Santiago.

A remoção desta alteração foi efectuada por limpeza mecânica, que consistiu em golpes sobre as camadas de incrustação com auxílio de bisturi e trincha de cedro fina, até remover os depósitos, seguida de lavagem geral em água corrente com escova. Para remoção das incrustações marinhas mais resistentes foi efectuado um tratamento químico, com uma solução de $50 \%$ de $\mathrm{C}_{2} \mathrm{H}_{5} \mathrm{OH}$ (etanol 96\%) e $50 \%$ de $\mathrm{H}_{2} \mathrm{O}$ (água desmineralizada), com ajuda de bisturi, estilete de madeira e cotonete feita com algodão hidrófilo e escova macia. Depois deste procedimento, foi realizada outra lavagem geral e a secagem natural completa por um período de 72 horas. Para consolidar a fissura da extremidade do alguidar foram aplicadas duas camadas de paraloid B-72 em 10\% de etanol. A proteção geral da superfície foi assegurada com paraloid B-72 em $5 \%$ de etanol. Para concluir, foi efectuada uma fotografia do estado final, o preenchimento da ficha de conservação e o armazenamento da peça na reserva técnica do Museu de Arqueologia.
3.5. Um projecto de gestão - a articulação com as outras entidades

O património arqueológico subaquático de Cabo Verde representa um enorme potencial, ainda pouco desenvolvido. Esse legado é de grande importância para a investigação científica, educação patrimonial, mas também para o desenvolvimento sustentável, com especial enfoque no turismo cultural.

A vulnerabilidade de Cabo Verde, país insular com recursos limitados, tem contribuído para que as suas águas territoriais sejam muitas vezes frequentadas por caçadores de tesouros, que aproveitam as fragilidades da vigilância marítima para pilhar um património de grande importância para o arquipélago, empobrecendo assim, o seu legado patrimonial subaquático.

Atendendo a estas limitações, a participação do IPC no projecto CONCHA foi encarada como uma oportunidade de melhorar a capacidade nacional na gestão do PCS. O IPC entendeu por isso envolver outros parceiros nacionais ligados à gestão do espaço marítimo, através de protocolos de colaboração. Entre estes parceiros, destacam-se a Polícia Marítima e o Comando da Guarda Costeira de Cabo Verde. A sua participação foi fundamental na execução das missões do projeto. Uma vez que o IPC não dispõe de meios logísticos para a realização de mergulhos, estes dois parceiros nacionais disponibilizaram toda a logística necessária, nomeadamente as embarcações e tripulações, que acompanharam as missões de campo, garantindo igualmente a segurança dos investigadores.

Partindo da experiência do CONCHA, de envolvimento de várias entidades na salvaguarda do património subaquático, o Governo de Cabo Verde deliberou a institucionalização desta parceria, através da criação da Comissão para a Proteção e Valorização do Património Subaquático de Cabo Verde (Resolução no 66/2018). Esta comissão multidisciplinar é constituída por entidades académicas e estatais ligadas a atividades marítimas, nomeadamente: Instituto do Património Cultural (IPC); Direção Nacional de Ambiente; Direção Geral do Património e Contratação Publica; Guarda Costeira; Polícia Marítima; Polícia Judiciária; Direção Geral do Turismo e Transportes; Universidade de Cabo Verde; Centros de Investigação ligados ao Mar; Comissão Nacional para UNESCO; Fundo de Sustentabilidade Social do Turismo e Instituto Marítimo e Portuária. 


\section{BALANÇO}

O trabalho desenvolvido até à data confirma o elevado potencial, científico e patrimonial, do PCS de Cabo Verde e demonstra a sua integração nas dinâmicas Atlânticas entre os séculos XV e XIX. A prospecção na Cidade Velha revelou a existência de extensos depósitos de superfície relacionados com a utilização portuária daquele espaço, incluindo ainda, pelo menos, os restos de um navio em madeira e concentrações de cerâmica que podem constituir contextos coerentes de naufrágio. O mapeamento dos naufrágios de São Francisco e Urânia permitiu novas interpretações sobre os sítios arqueológicos e a sua formação. No seu conjunto, estes contextos documentam várias fases da navegação no Atlântico na época moderna, sendo particularmente significativos o fundeadouro da Ribeira Grande de Santiago e os restos do naufrágio de São Francisco, relacionados com o comércio de escravos.

Os dados disponíveis permitem também dar corpo a um inventário georreferenciado do PCS de Cabo Verde, servindo como situação de referência à adopção de medidas de protecção, monitorização e valorização.

A documentação gráfica (fotografia, vídeo, modelos e desenho) tem também potencial que vai além da investigação, permitindo a sua apresentação e divulgação em vários suportes - publicações, painéis, vídeos e documentários. O mapeamento do Urânia, por exemplo, permite a criação de um roteiro de visitação, e poderá dar lugar à criação de um parque arqueológico subaquático, um valor turístico acrescentado. As acções socioeducativas desenvolvidas a partir do Museu de Arqueologia permitiram melhorar a sua comunicação com o público, atingindo várias faixas etárias.

O trabalho foi também particularmente positivo na articulação entre todos os parceiros e participantes, incluindo a Polícia Marítima e a Guarda Costeira, constituindo uma experiência única em países lusófonos, que culminou na criação da Comissão para a Proteção e Valorização do Património Subaquático de Cabo Verde.

Deste modo, considera-se importante dar continuidade a este projecto, através do aprofundamento da investigação na ilha de Santiago; do alargamento do trabalho a outras ilhas, adoptando a mesma estratégia de avaliação não intrusiva dos sítios já conhecidos; do fomento do acesso a sítios de baixa sensibilidade; do desenvolvimento de actividades de formação especializada em ambiente de investigação, garantindo a transferência de conhecimento e a colaboração, nomeadamente com outros projectos; e de acções de divulgação e sensibilização das comunidades para a importância do património cultural subaquático.

\section{AGRADECIMENTOS}

Este trabalho só foi possível com o apoio e a cumplicidade de várias pessoas e instituições. Gostaríamos de agradecer ao Presidente do IPC, Hamilton Lopes Fernandes, o empenho neste projecto desde o primeiro momento. O apoio logístico da Polícia Marítima e da Guarda Costeira foi essencial e uma experiência de partilha dificilmente repetível.É impossível enumerar todos os participantes, mas não podemos deixar de destacar o Comandante Faustino Moreno Sanches e os Agentes Paulo Furtado e Adélio Silva, da Polícia Marítima, e o Director de Operações Capitão de Patrulha Silvino Chantre e o Comandante do navio Djeu, $1^{\circ}$ Tenente Adérito Cardoso, da Guarda Costeira, enquanto representantes de ambas as Instituições. Agradecimento também particular a Emanuel Charles de Oliveira e a Alexandre Semedo, com quem demos os primeiros mergulhos em águas cabo-verdianas.

Este projecto foi financiado pela UE-H2O2O-MSCA-RISE-2017 ao abrigo do programa de investigação e inovação sob o acordo de projecto $\mathrm{n}^{\circ}$ 777998; This project has received funding from the EU H2O2O-MSCA-RISE-2O17 research and innovation programme under grant agreement № 777998 .

\section{BIBLIOGRAFIA}

AMORES CARREDANO, Fernando e CHISVERT JIMÉNEZ, Nieves (1993) - Tipologia de la cerâmica común bajomedieval y moderna Sevillana (ss. XV-XVIII): La loza quebrada de relleno de bóvedas. SPAL, 2, pp. 269-325.

ASSIZ, Janette Jean Corrêa de (2017) - A Disseminação da Informação por meio dos Museus: O caso do Museu do Tribunal de Justiça do Estado do Pará, Trabalho de Conclusão de Curso- Grau Bacharel, Pará: Universidade Federal do Pará.

CARDOSO, Renato (1984) - Relatório do Grupo de Trabalho Sobre Pesquisas Arqueológicas, de 26 de Novembro de 1984. Praia, Arquivo do Museu de Arqueologia - IIPC.

D'OLIVEIRA, Emanuel Charles (2005) - Cabo Verde na rota dos naufrágios. Praia, s/ ed. 
ESPARTEIRO, António Marques (1979) - Três Séculos no Mar 1640/1910 - III Parte/Fragatas/3ํ. Volume, Lisboa: Ministério da Marinha (Colecção Estudos).

MOORE, D. D. e MALCOM, C. (2008) - SeventeenthCentury Vehicle of the Middle Passage: Archaeological and Historical Investigations on the Henrietta Marie Shipwreck Site. International Journal of Historical Archaeology, 12(1), pp. 20-38.

SMITH, B. S. (2002) - An astrolabe from Passa Pau, Cape Verde Islands. The International Journal of Nautical Archaeology, 31.1, pp. 99-107.

TORRÃO, M. M. e TEIXEIRA, A. (2009) - Negócios de escravos de um florentino em Cabo Verde: descrições e reflexões sobre a sociedade e o tráfico em finais do século XVI, em linha, disponível em URL: http://cvc.instituto-camoes. pt/eaar/coloquio/comunicacoes/mmtorrao_ateixeira.pdf, consultado a 1 de Julho de 2019.

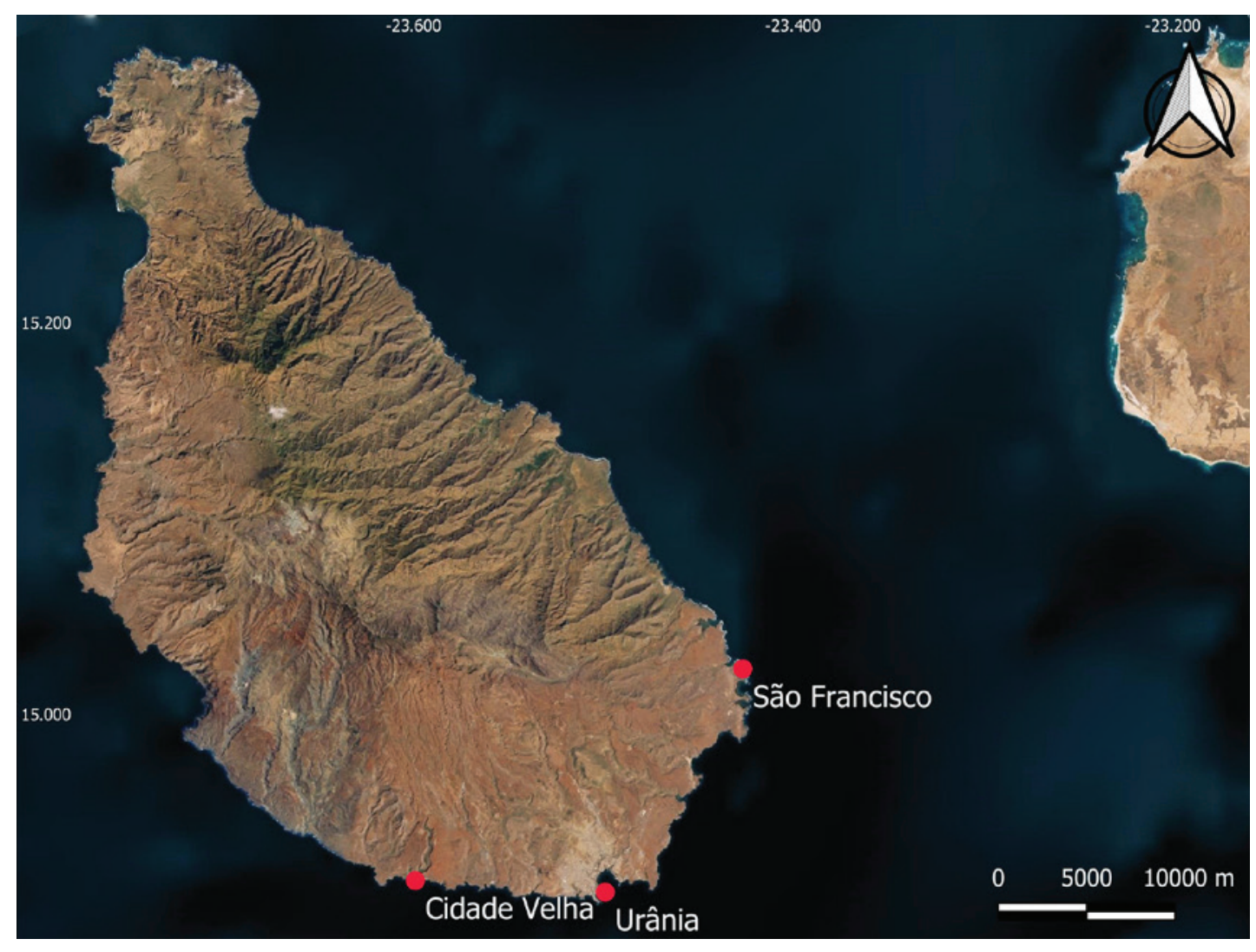

Figura 1 - Localização dos sítios intervencionados na ilha de Santigo (imagem base: Bing Sattelite). 


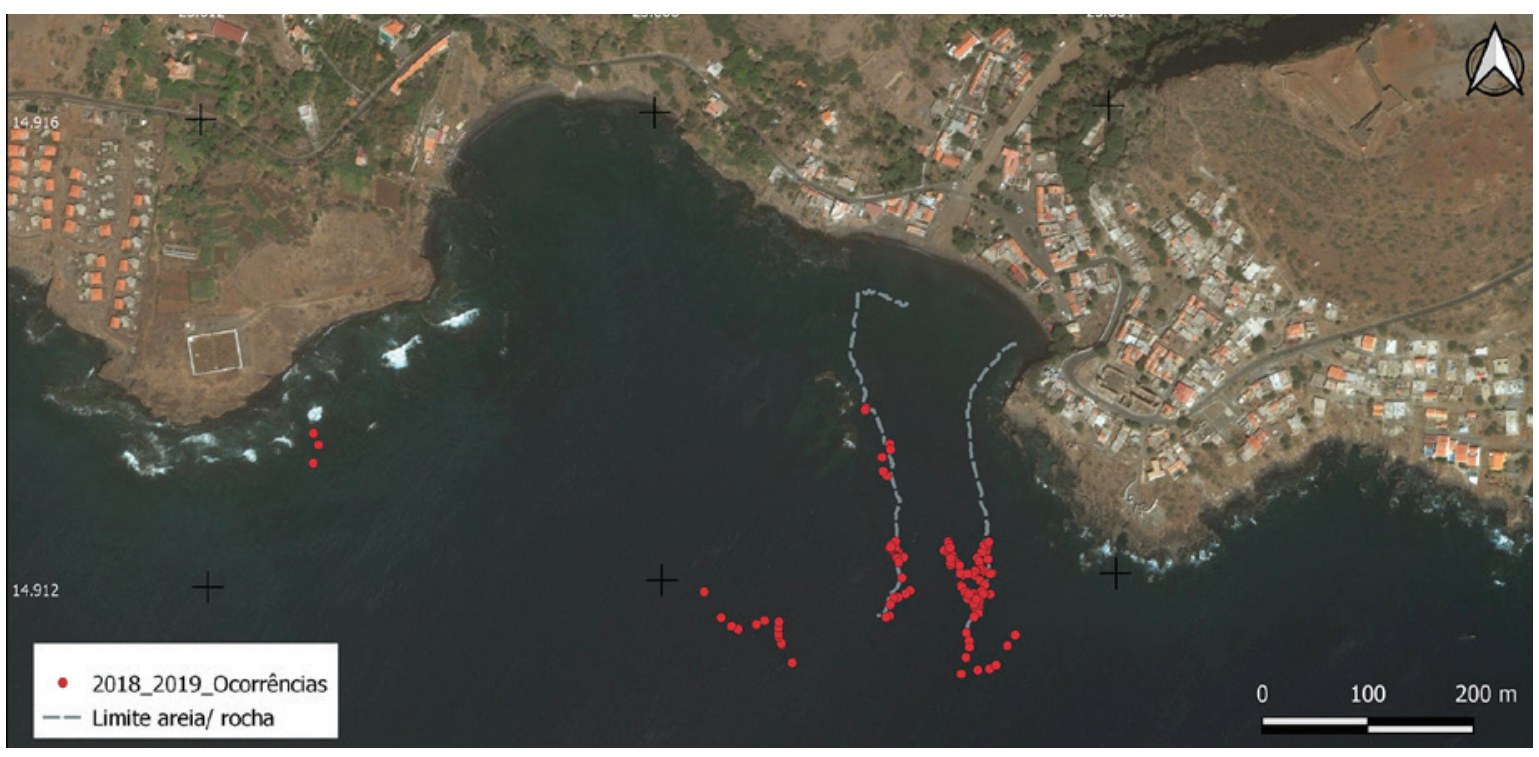

Figura 2 - Distribuição geral das ocorrências identificadas no fundeadouro da Cidade Velha.
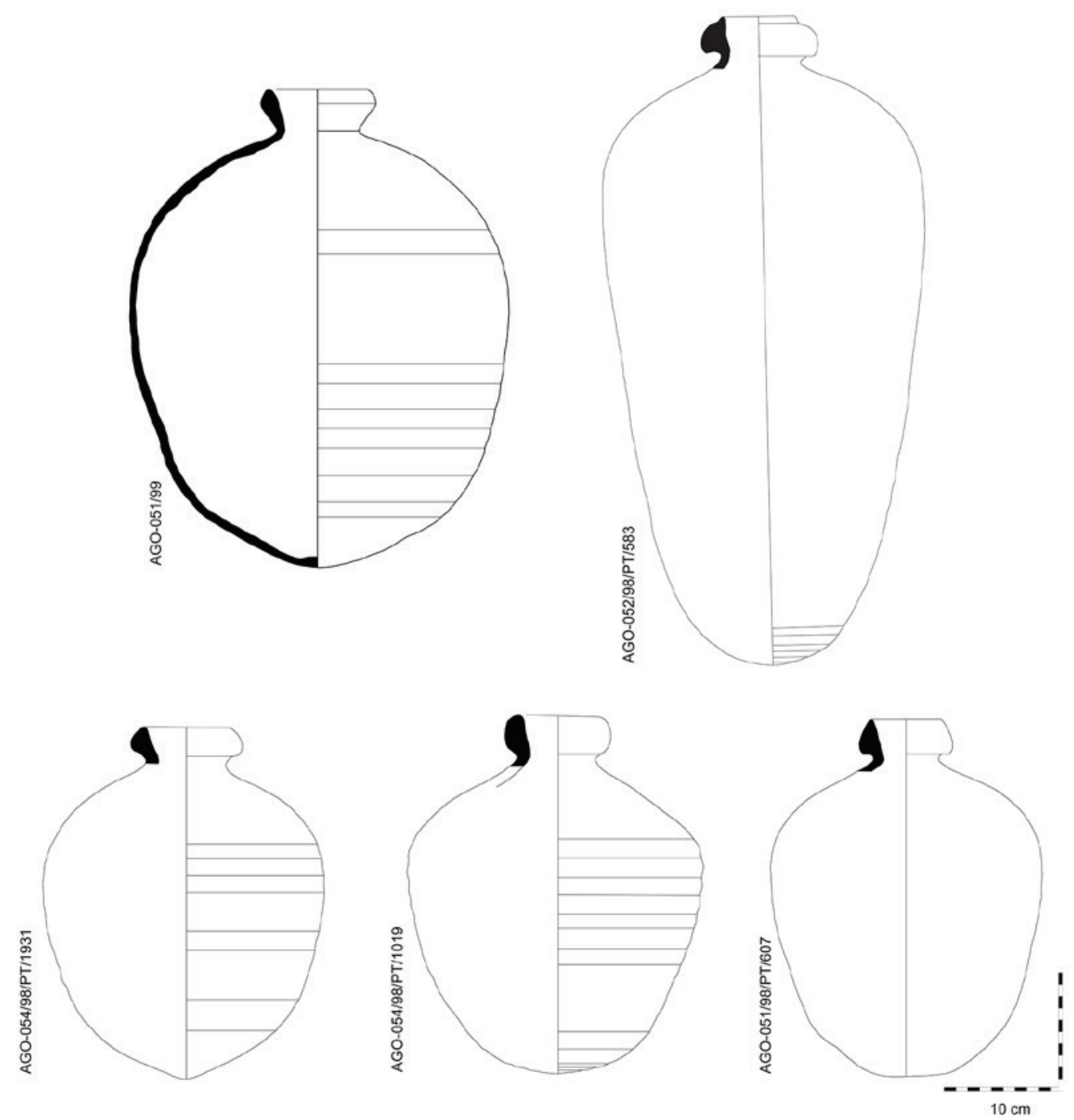

Figura 3 - Botijas, com fabricos andaluzes, recuperadas na Ribeira Grande de Santiago pela empresa Arqueonautas S.A.. 

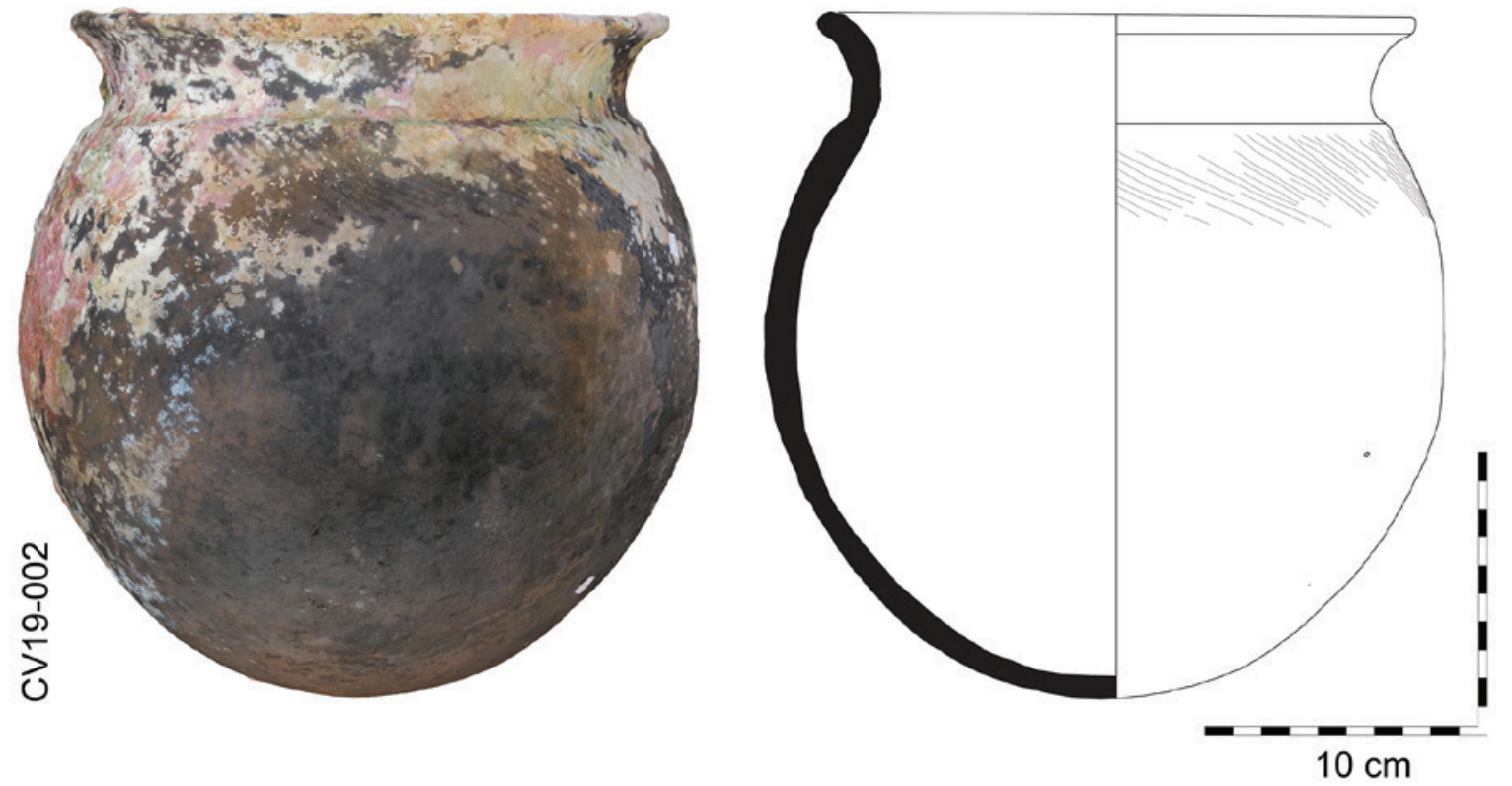

Figura 4 - Cerâmica de tradição africana, recuperada pelo CONCHA no fundeadouro da Cidade Velha.

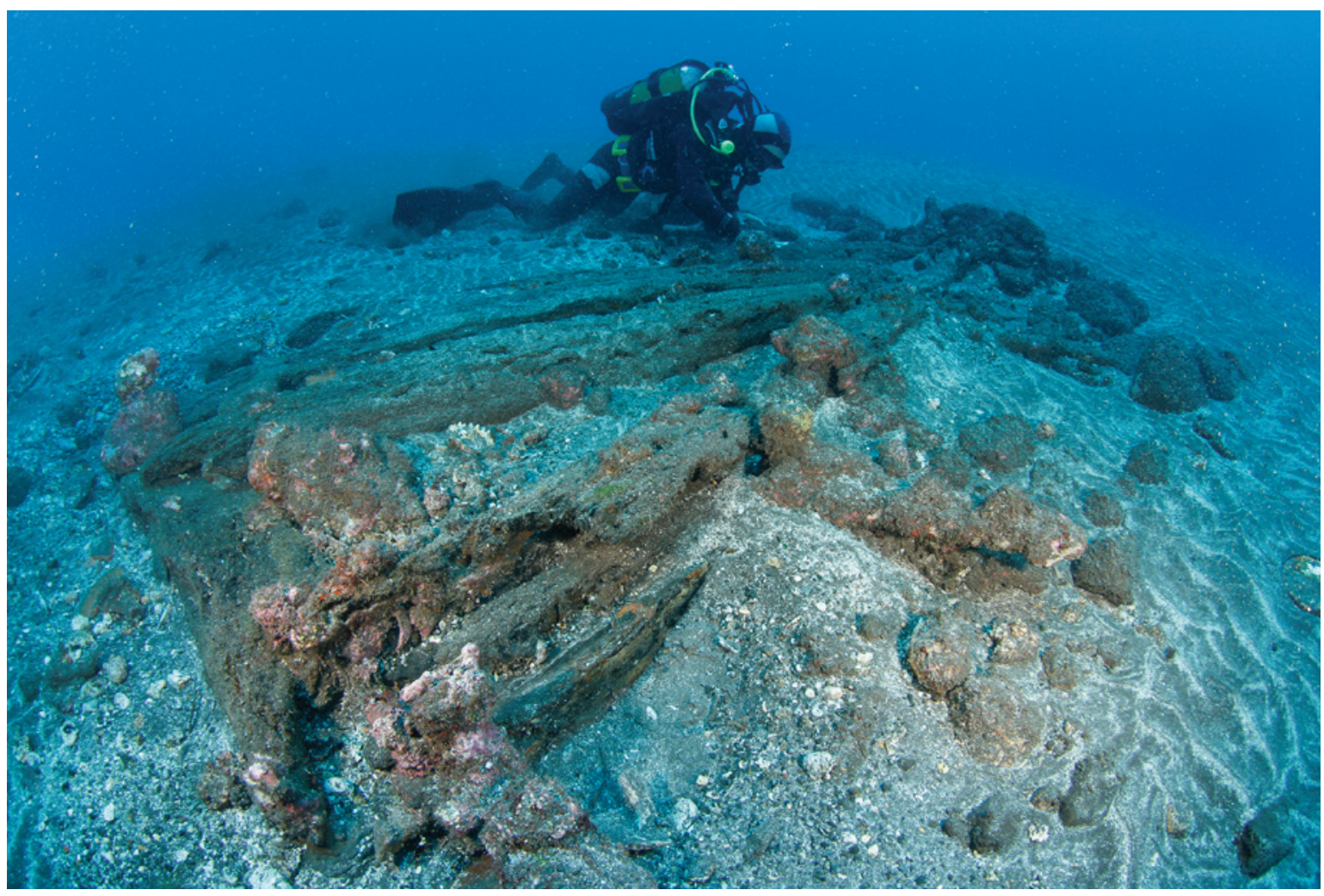

Figura 5 - Vista geral do navio Cidade Velha 1, a partir de sul (foto: José Bettencourt). 

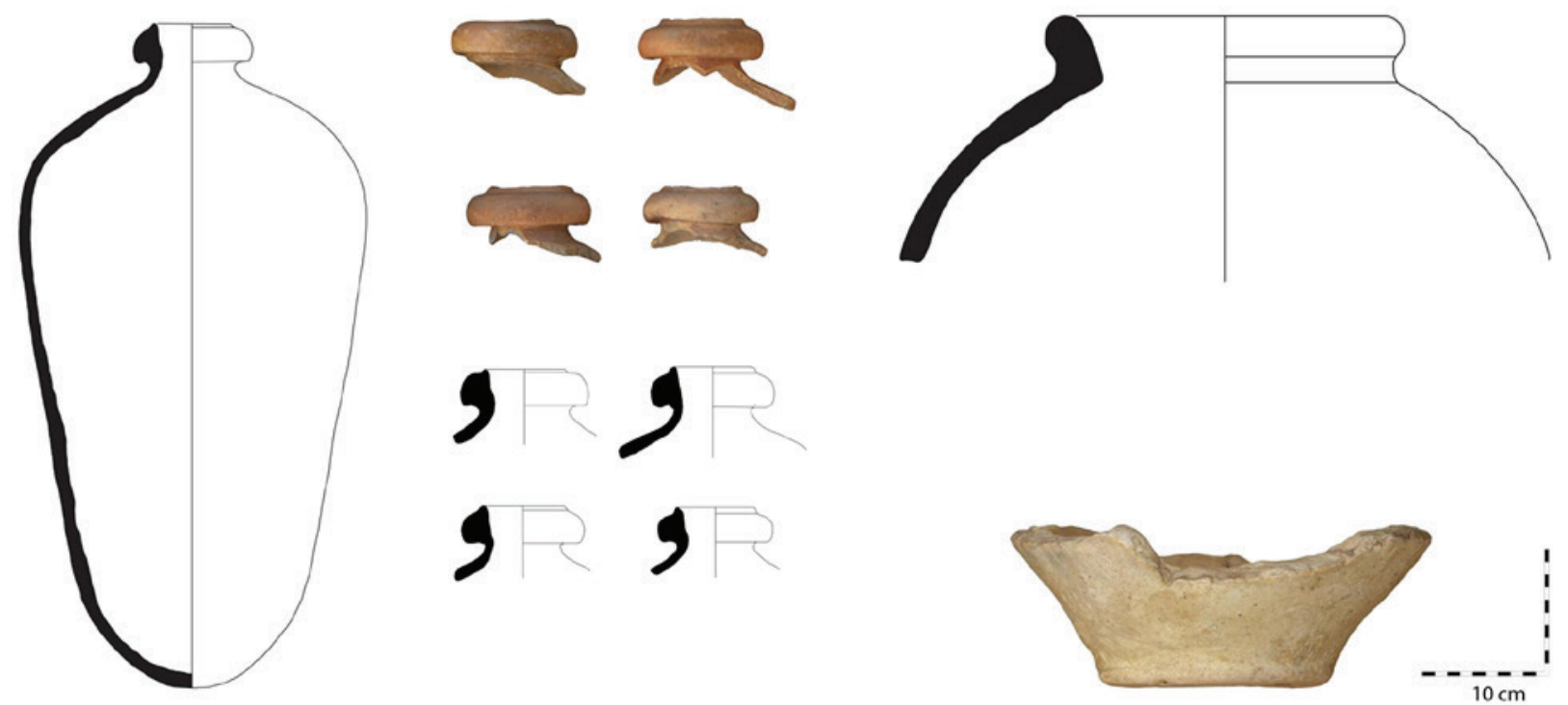

Figura 6 - Botijas e talhas recuperadas no naufrágio de São Francisco pela empresa Arqueonautas S.A..

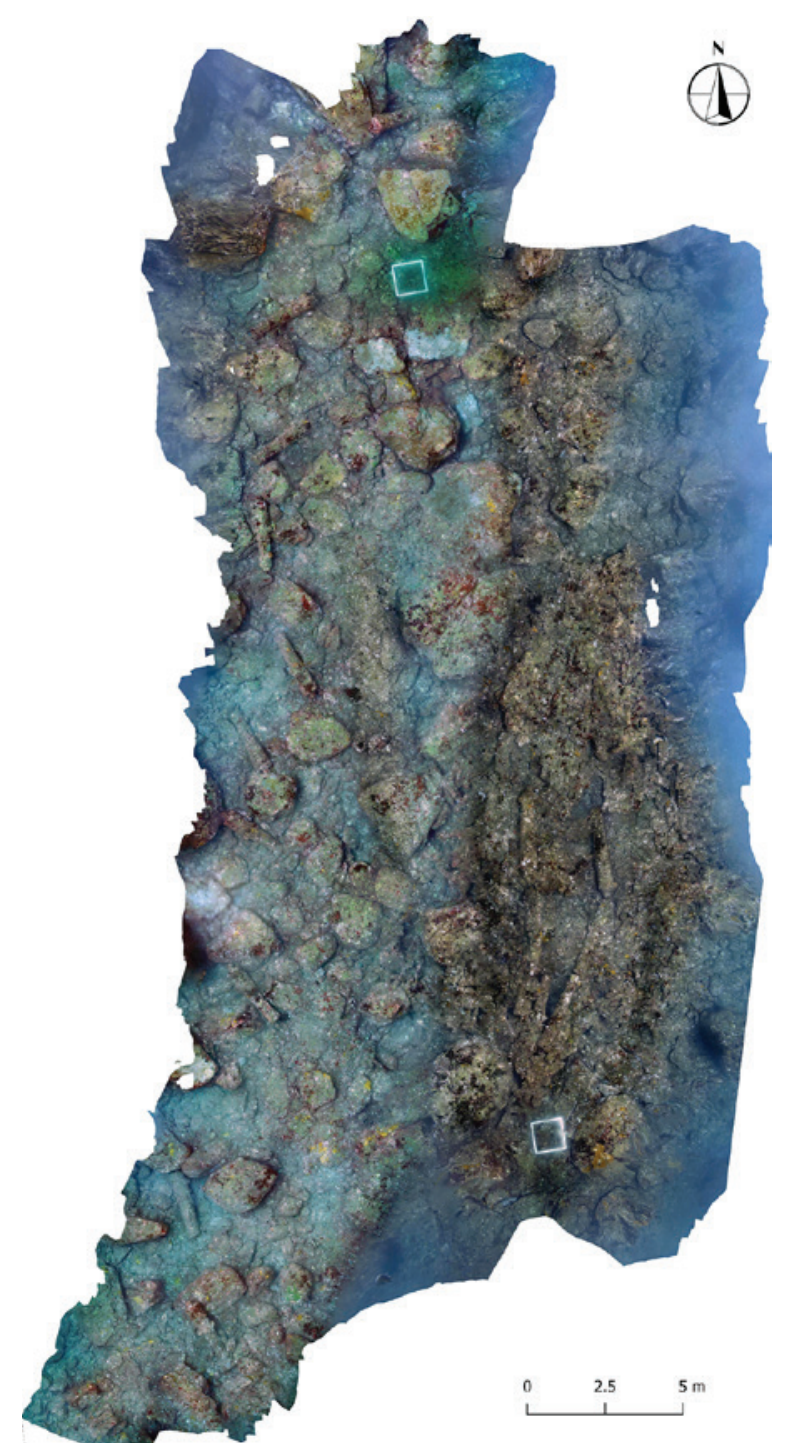

Figura 7 - Ortofotomapa do naufrágio do Urânia (versão 1, de Agosto de 2018). 


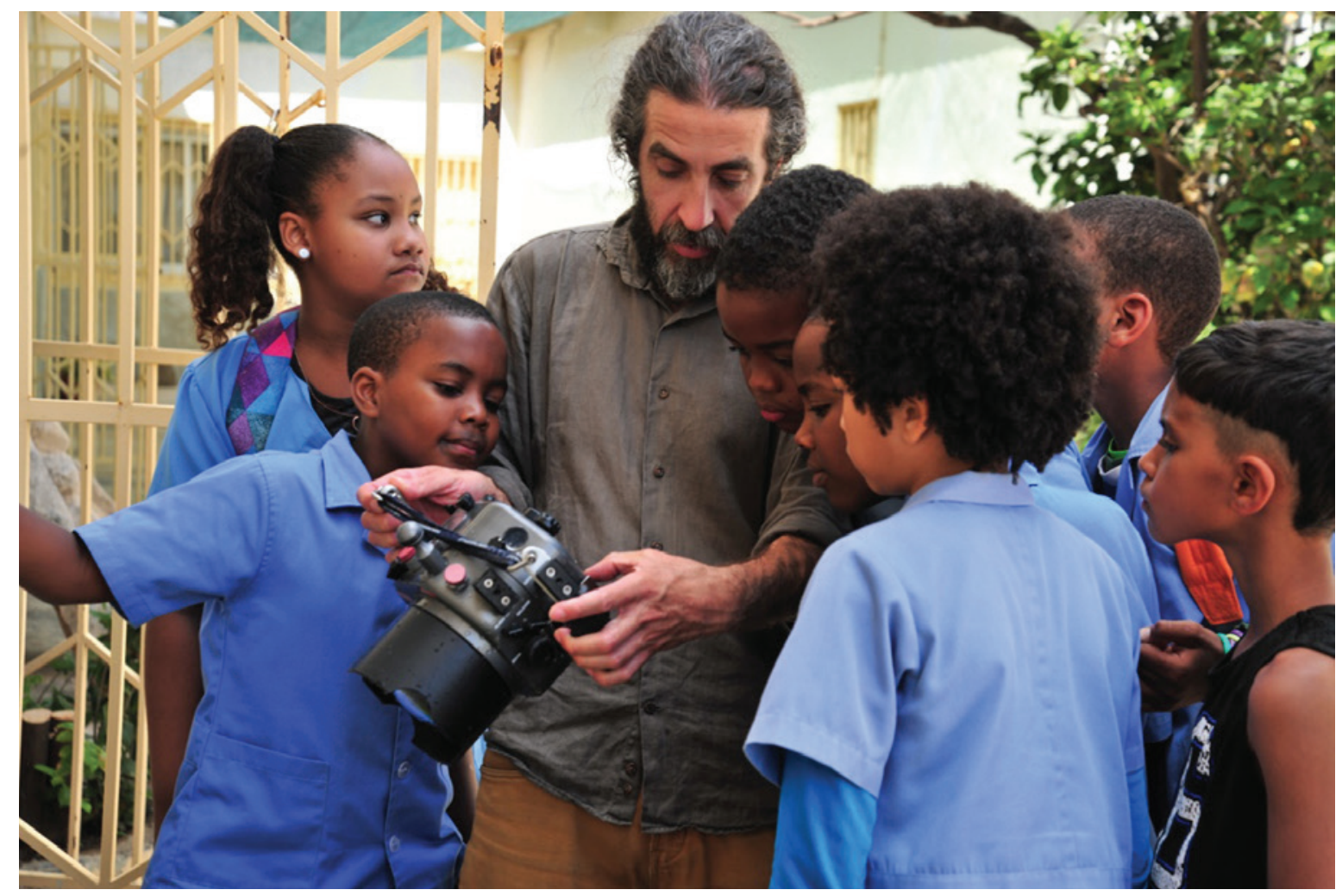

Figura 8 - Aspecto das acções de divulgação e sensibilização para o público escolar, desenvolvidas no Museu de Arqueologia da cidade da Praia (foto: IPC). 



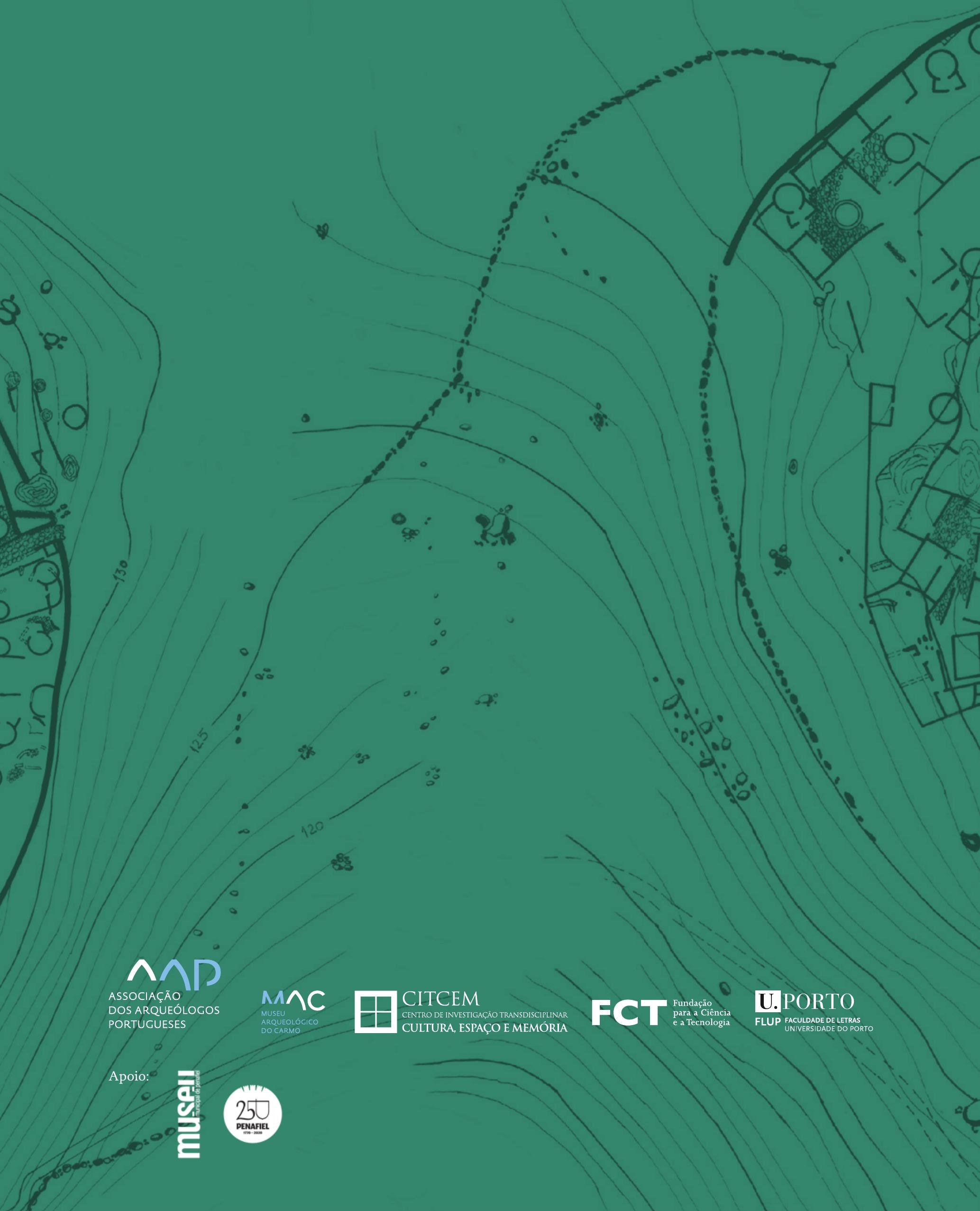

